\title{
THE ARMOR OF DEMOCRACY: VOLUNTEERISM ON THE HOME FRONT IN WORLD WAR II \\ CALIFORNIA
}

\author{
A Thesis \\ Presented to \\ The Faculty of California Polytechnic State University, \\ San Luis Obispo
}

\author{
In Partial Fulfillment \\ of the Requirements for the Degree \\ Master of Arts in History \\ by \\ Christopher Michael Head
}

March 2009 
(C) 2009

Christopher Michael Head

ALL RIGHTS RESERVED 


\section{COMMITTEE MEMBERSHIP}

TITLE:

The Armor of Democracy: Volunteerism on the Home

Front in World War II California

AUTHOR:

Christopher Michael Head

DATE SUBMITTED:

March 2009

COMMITTEE CHAIR:

Dr. Thomas R. Trice, Associate Professor

COMMITTEE MEMBER: Dr. George B. Cotkin, Professor

COMMITTEE MEMBER: $\quad$ Dr. Robert Detweiler, Professor 


\begin{abstract}
The Armor of Democracy: Volunteerism on the Home Front in World War II California

Christopher Michael Head
\end{abstract}

This paper is an in-depth study on the role of Home Front Volunteerism in California during World War II. It argues that Volunteerism was integral to America's eventual victory. This paper fills a gap in historical writings on World War II and shows that Volunteerism is a topic worthy of study. Volunteerism played a major role in California. It helped to keep morale high even when the war was progressing poorly. Volunteerism also helped to create new communities out of those shattered by the upheaval of the Great Depression. It provided a patriotic outlet for Americans desperate to aid the war effort. Minority groups took part in volunteer activities in order to show that they too were Americans and in doing so raised their status in society. Throughout the war, volunteers collected scrap metal which was melted down into weaponry. "Radishy victory gardens" sprung up throughout California. The Red Cross experienced an unprecedented surge in volunteerism and new methods in preservation and transportation of donated blood saved thousands of lives. The USO, created during the war, provided entertainment to soldiers both on the home front and overseas. Celebrities and civilians volunteered with the USO. This paper discusses many other ways in which Californian's volunteered. Each volunteer activity provided an outlet for Americans desperate to aid the war effort in any way that they could. 


\section{ACKNOWLEDGMENTS}

I inherited my interest in World War II from my Grandfather, Richard Lampke.

He was too young to fight in World War II, but served in the Korean War. I recall visiting his house in Carpinteria, California, since the time I was very young, and perusing his collection of World War II history books, most notably Time-Life's multi-volume collection World War II. I attribute my love of World War II, and history in general to his influence on me.

In High School I had two teachers that helped to make me the historian I am today. Dr. Geraldine May's A.P. English classes taught me a great deal about writing. By requiring a three to five page essay (usually analyzing poetry or a short story) each week, Dr. May's class taught me much about writing when under heavy time constraints. I would not be the writer that I am today without her guidance. Mrs. Barbara Reiger's History class, more than anything else, convinced me to pursue history as a profession.

I would also like to thank all of the faculty and staff of the Cal Poly History Department who have aided me throughout my education at Cal Poly. I wish to extend my eternal gratitude to Dr. George Cotkin for guiding me throughout my Cal Poly experience. From history 304, to my senior project, graduate seminars, and my thesis, Dr. Cotkin has been my closest advisor. I would also like to thank him for continuing to advise my thesis while on sabbatical. I would also like to thank Dr. Tom Trice and Dr. Robert Detweiler for agreeing to be on my defense committee and for providing me with insightful comments, many of which affected the final version of this paper. I would also like to mention and thank Dr. Paul Hiltpold for his influence on my writing style. 
I would like to thank the staff at the National Archives (NARA) Pacific Region at Laguna Niguel for their friendliness and helpfulness in aiding my research. I would also like to thank my friend Joseph Ward for letting me stay at his apartment in Fullerton while I was conducting my research at Laguna Niguel.

I would like to conclude by thanking my parents for their unyielding support. I also would like to offer my personal acknowledgements and thanks to any one whom I may be remiss in mentioning. 
TABLE OF CONTENTS

Page

ABBREVIATIONS OF ORGANIZATION NAMES ....................... ix

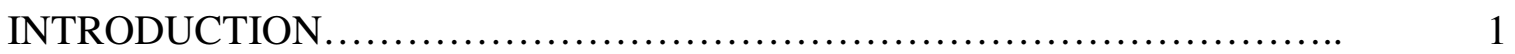

WHAT CAME BEFORE?: A BRIEF HISTORIOGRAPHY OF THE HOME

FRONT IN WORLD WAR II .......................................... 5

A LEGACY OF SERVICE: AMERICAN WAR TIME VOLUNTEERISM

PRIOR TO WORLD WAR II........................................ 9

ON THE PRECIPICE: VOLUNTEERISM IN CALIFORNIA ON THE EVE OF

WORLD WAR II........................................................ 12

WAR COMES TO THE GOLDEN STATE: CIVIL DEFENSE VOLUNTEERISM

IN THE CHAOS OF WAR................................................ 18

“HIT HITLER WITH THE JUNK!”: DID DONATED AUTOMOTIVE FLOOR MATS WIN THE WAR?

TO EVERY HOME A GARDEN AND TO EVERY SOLDIER A LETTER:

VICTORY GARDENS AND LETTERS TO THE FRONT, PUBLICLY INITIATED

VOLUNTEERSIM IN WORLD WAR II CALIFORNIA....................... 38

A TRADITION OF VOLUNTEERISM: THE RED CROSS ................... 43

HOLLYWOOD JOINS THE BATTLE, BUT EVEN YOU CAN ENTERTAIN THE

TROOPS: CELEBRITIES, CIVILIAN, THE USO, AND VOLUNTEERISM....... 49

VOLUNTEERISM IN A HETEROGENEOUS CULTURE: RACE AND

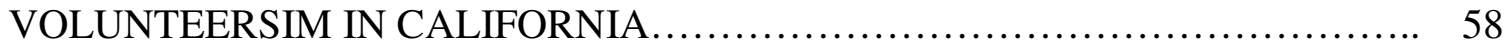

POTENTIAL FIFTH COLUMN: JAPANESE AMERICAN VOLUNTEERISM

BEFORE AND DURING INTERNMENT ................................ 67

THE “GOOD” ASIAN IN THE “GOOD” WAR: CHINESE AMERICAN

VOLUNTEERISM IN WORLD WAR II CALIFORNIA ....................... 72

AFTER V-DAY: WORLD WAR II, CALIFORNIA, AND CHANGE............. 77 
DID RUBBER MATS AND VICTORY GARDENS WIN THE WAR?:

CONCLUSIONS REGARDING THE CENTRALITY OF VOLUNTEERISM

ON THE HOME FRONT IN CALIFORNIA

EPILOGUE: MASS VOLUNTEERISM IN CALIFORNIA.....................

SINCE WORLD WAR II

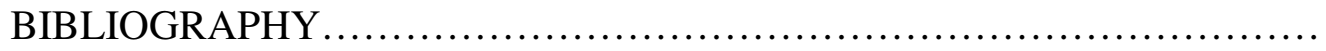


American Civil Liberties Union................................ACLU

American Women's Volunteer Service...........................WVS

Chinese War Relief Association................................WRA

Chinese Young Women's Society...............................WS

Native Sons of the Golden West..............................SGW

Office of Civilian Defense............................................D.

Office of War Information.....................................WI

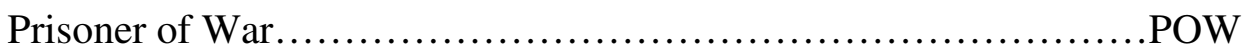

United Service Organizations................................USO/U.S.O.

Women's Army for National Defense...........................WAND

Women's Auxiliary Corps................................WAC

Young Men's Christian Association............................YMCA 
Jim isn't home tonight. He's over at the fire department learning about incendiary bombs. I told him I'd heard that our local Civilian Defense organization was going to appoint me the block leader in our block. But he says I've got too much to do already... sewing at Red Cross every afternoon, cooking, and cleaning.

But, my goodness, Jim, I said, everybody's got to do as much and even more than he can. Jim, I said, aren't you on the Demolition Squad by night and an assistant warden for your office building by day - and, anyway, whatever we do compared to what the boys in uniform have to do, it don't amount to a thing!

Excerpt from: "Yankee Doodle": A 15-minute Radio Drama on Civilian Defense. Office of War Information, 31 October 1942. ${ }^{1}$

\footnotetext{
${ }^{1}$ Box 55, RG 171, National Archives Laguna Niguel.
} 
After the horrors of the surprise attacks on Pearl Harbor were fully realized, a sleeping giant was awakened. Almost immediately, Americans-filled with emotionenlisted in the war effort. Many joined the armed services. Others volunteered their time in different ways. Lines at blood banks stretched around the block and care packages were assembled for soldiers abroad. Across the nation, average citizens poured into the streets in parades celebrating their country and their patriotism. The outburst of volunteerism in response to the surprise attacks on Pearl Harbor and the United States' subsequent entry into World War II resonated throughout the nation.

In California, the spirit of volunteerism was especially strong. Over 750,000 men from the state, throughout the duration of the war, voluntarily joined the armed forces. ${ }^{2}$ Though this type of volunteerism is noble and was vital to the war effort, armed service volunteerism is not the focus of this paper. Rather this study will focus on volunteerism on the California home front. Californians volunteered in many ways and each person

\footnotetext{
${ }^{2}$ Roger W. Lotchin, ed., The Way We Really Were: The Golden State in the Second Great War (Urbana: University of Illinois Press, 2000), 2.

The 1940 federal census recorded a population of approximately 6,900,000 for California. By 1950, the population had reached ten million. If one allows for population growth throughout the war, by mid decade it can be estimated that the population of California was approximately 8,500,000. Using this estimated population one discovers that the 750,000 men that volunteered to join the armed forces made up roughly nine percent of California's total population throughout the duration of the war. Other states experienced rapid population increase as well, particularly those on the East Coast and the other West Coast states. Nationally during the course of the decade between 1940 and 1950 1,560,000 people migrated to the Western United states whereas only 400,000 left those states for other regions of the nation. Nearly $1,290,000$ people migrated out of the South while 1,120,000 would migrate to the south from other national regions. The North by and large would be affected the most by the national migrations of the 1940s and 1950s. Whereas only 900,000 migrated there from other parts of the country, 1,890,000 left the region. California Census figures from:

Richard L. Forstal, ed, "Population of Counties by Decennial Census: 1900 to 1990" in U.S. Census Bureau [cited 10 October 2008]; available from: http://www.census.gov/population/cencounts/cal190090.txt

Population movement patterns from: Joyce Appleby, Alan Brinkley, Albert Broussard, James McPherson, and Donald Ritchie, The American Vision: Modern Times (New York: McGraw Hill Glencoe, 2006), 589.
} 
was motivated by different factors. Most Californians volunteered as a way to support a loved one fighting overseas, but there were many other motivating factors as well. Some men volunteered in civil defense to protect their families. Others, deemed 4-F, unqualified for military service due to health issues, volunteered to prove their manhood. Women viewed volunteerism as a way of moving towards gender equality and volunteered for many of the same positions as men. Minority groups used volunteerism to show their patriotism and to increase their status in mainstream society. As a way of promoting full participation, the government, through the Office of Civilian Defense (OCD) and Office of War Information (OWI), actively promoted volunteerism and racial unity. Though each group met with varying success in its goals, the facts are clear, the United States won the war, and volunteerism aided in that victory.

Volunteerism benefited largely from the enthusiasm of the general public and the support and active encouragement of federal, state, and local governments. Though the end results of such voluntary efforts as scrap drives and paper drives was often material of dubious significance to the actual mechanics of fighting the war, they served to create a feeling of community and patriotism along with bolstering support for the war. In a time of intense population mobility, Volunteerism served as a uniting factor for those that moved to California from other parts of the country. Though they still retained strong identities from the states in which they previously resided, they became Californians. ${ }^{3}$ Voluntary efforts increased morale as nearly every Californian participated and felt a very real and intimate involvement in the war effort. Such efforts allowed the average citizen to feel intimately involved in the war effort. Amid the chaos and confusion of the

\footnotetext{
${ }^{3}$ This study uses the catch-all term Californians to describe people living in California during World War II. Though many moved to California in search of war work, they became de-facto Californians in their support of civil defense efforts and other community building volunteer activities.
} 
initial days after the Pearl Harbor attacks those who volunteered for costal defense provided a sense of regulation, decorum, and control to the ever present air raid drills and nightly blackouts.

Volunteerism proved integral in keeping the public involved in the war effort in California. Because of California's vulnerability to attack from the Japanese, the experience of its wartime volunteers differed from much of the rest of the nation. An unfortunate aspect of this vulnerability was that anti-Japanese behavior and activities were viewed as a most noble way of aiding the war effort. Yet others, mostly Christian groups, stressed the need to care for one's fellow man and show charity towards the displaced Japanese Americans. This group, predominately Methodist and led by the National Council of Churches, aided the war effort by fighting to give the Japanese an equal chance to support the American war effort. California's diverse geography, cultures, and people served to differentiate the state from much of the rest of the nation. Masses of people migrated to California in search of war work and with a full quarter of the national population mobile at one time or another during the war, the California that emerged afterward was different. The mixture of whites, Hispanics, African Americans and Asian Americans provided California with a unique set of challenges that at times devolved into violence. ${ }^{4}$ Chinese Americans, a group that had long been abused experienced unprecedented cultural gains. As an example of patriotism, volunteerism in Chinese American communities facilitated a rise in status and was a method of becoming

\footnotetext{
${ }^{4}$ The most recognized example of interracial relationships devolving into violence in World War II California are the infamous Zoot-Suit Riots. Between the third and the tenth of June 1943, American soldiers brawled with Mexican-American Zoot-Suiters in the worst riot Los Angeles had seen to that point in the twentieth century. For more information please see:

Edward J. Escobar, "Zoot-Suiters and Cops: Chicano Youth and the Los Angeles Police Department during Word War II," in The War in American Culture: Society and Consciousness During World War II, ed. Lewis A. Erenberg and Susan E. Hirsch (Chicago: The University of Chicago Press, 1996), 284-309.
} 
a part of the mainstream of society. The treatment of minority groups in California demonstrates the paradoxical nature of volunteerism during the war. Though communities were created and strengthened across the state, these communities were mostly homogeneous in nature. Aside from Chinese American efforts, volunteerism by California's minority groups was largely ignored in white dominated areas of the state. Excluded by most of the mainstream community, minority groups in California volunteered in their own organizations and created their own communities while they fought to make societal gains. Throughout the war, various voluntary efforts united Californians and created a sense of participation in a war being waged thousands of miles from home. Volunteerism was vital to winning the war on the home front and as this paper will show is largely underappreciated and undervalued by the greater academic community. 


\section{WHAT CAME BEFORE?: \\ A BRIEF HISTORIOGRAPHY OF THE HOME FRONT IN WORLD WAR II}

There is a dearth of material dedicated specifically to volunteerism on the California home front in World War II. Perhaps this is because historians have not viewed volunteerism as a topic worthy of much research. This paper will prove otherwise; volunteerism was in fact essential to the war effort and helped to win the war by improving morale and creating a strengthened sense of community. All of the works mentioned in this historiography devote some space to volunteerism, at least in passing, but few dedicate more than a few pages to the topic.

Much effort has been devoted to the study of the home front in World War II. John Morton Blum's V Was for Victory: Politics and American Culture during World War II is one of the most significant studies of the history of the home front. Blum does not seek to provide a comprehensive history of the home front during World War II but selects specific facets of politics and culture during the war to use as launching points for his study. ${ }^{5}$ He argues that those who ran the war effort at home did not intentionally use the war "to convert the governed, or as a laboratory of democracy, or as a crusade for universal peace." ${ }^{\prime 6}$ Essentially, Blum argues that though the war served as a harbinger of changes in American society, those who orchestrated the war effort did not intend it to effect society as much as it did. Instead, change was an unintended consequence of the war. World War II became a crusade for universal peace and a war for democracy, but not solely due to a concentrated effort by those that were running it. In contrast to Blum,

\footnotetext{
${ }^{5}$ John Morton Blum, V Was for Victory: Politics and American Culture during World War II (New York: Harcourt Brace Jovanovich, 1976), xi.

${ }^{6}$ Blum, V Was for Victory, 14.
} 
evidence presented in this study shows that governmental organizations such as the Office of Civilian Defense (OCD) and Office of War Information (OWI) actively sought to use the war as a means of promoting racial and cultural unity, in the very least for the duration. There are several other works focusing on the home front during World War II, but Blum's is almost universally accepted as the most significant. ${ }^{7}$

Some studies focus more specifically on the home front in World War II California. Historian Roger W. Lotchin has been integral to the study of California during the war. His book, The Bad City in the Good War: San Francisco, Los Angeles, Oakland, and San Diego, argues that World War II is one of the few "nearly universal" experiences in modern American history and uses volunteerism as evidence of the universality of the war. ${ }^{8}$ Though this paper does not dispute this fact, it delves much deeper into the concept of volunteerism. Though volunteerism was practiced by most residents of California during the war, gender and racial divides shaped the people's voluntary experience. In essence, World War II was a "nearly universal" experience in California, yet different groups experienced it in decidedly different ways. Even within California's minority groups experiences differed. Lotchin also edited a collection of essays titled The Way We Really Were: The Golden State in the Second Great War. This work was the first singlevolume history of World War II in California. ${ }^{9}$ Even more specifically, there are books that focus on specific areas of California during World War II. One such example is Stan

\footnotetext{
${ }^{7}$ Please see this paper's bibliography for a more complete listing of works focusing on the home front during World War II.

${ }^{8}$ Roger W. Lotchin, The Bad City in the Good War: San Francisco, Los Angeles, Oakland, and San Diego (Bloomington: Indiana University Press, 2003), 2.

Lotchin's complete thesis: "For Americans, World War II was perhaps the most nearly universal experience of the twentieth century. Hardly anybody was unaffected by it." Other universal American experiences in the $20^{\text {th }} / 21^{\text {st }}$ centuries include the Great Depression and 9/11.

${ }^{9}$ Lotchin, ed., The Way We Really Were, 2.
} 
Harth, Liz Krieger, and Dan Kreiger's War Comes to the Middle Kingdom: Vol. 1-19391942 which focuses on the south-central coast of California. ${ }^{10}$

There are a variety of works devoted to the roles of women in World War II, most of which focus at least in part on volunteerism. Emily Yellin's Our Mothers' War: American Women at Home and at the Front During World War II discusses the varying roles that women played in the war. She uses her own mother's experience as a starting point for her study, in which she concludes: "I began to see those four years of the war as a kind of inadvertent revolution in America, a time when, while men were not really watching, women all over this country from every walk of life learned they could accomplish things they had never been allowed or asked to try before." 11

Doris Weatherford's American Women and World War II is another significant study of women in World War II. She also argues that World War II served as a sort of revolution for women. She argues; "Although any society at war must subject its members to greater regimentation, to loss of accustomed freedoms and to altered lifestyles, it will allow_even encourage-women in wartime to do things that are closed to them in peace."12 Weatherford contradicts Yellin's "gender revolution" thesis. She argues that once peace returned, many of the opportunities that opened up to women for the first time during World War II were once again unattainable. Weatherford devotes an entire

\footnotetext{
${ }^{10}$ Stan Harth, Liz Krieger, and Dan Krieger, eds. War Comes to the Middle Kingdom: Vol. 1 1939-1942 (San Luis Obispo, Ca: EZ Nature Books, 1991).

On page ix of their work, Harth, Krieger, and Krieger, define the south-central coast of California as northern Santa Barbara County and San Luis Obispo County. This mostly rural region of California, even today," seems a bit removed from the hustle and bustle of world events" according to Harth, Krieger, and Krieger.

${ }^{11}$ Emily Yellin, Our Mothers' War: American Women At Home and At the Front During World War II (New York: Free Press, 2004), xiv.

${ }^{12}$ Doris Weatherford, American Women and World War II (New York: Facts on File, 1990), ix.
} 
chapter to volunteerism. Her thesis is highly critical of female volunteerism and volunteerism in general;

Volunteerism, by its very nature could easily be seen as a band aid on a wound that needed surgery, with the result that women who were doing all that they could do were viewed by critics as having only a part-time commitment to a fulltime problem. Worse, often the effort that they made was just enough to allow the public to assuage its conscience with the belief that something was being done, and thus, ironically, to make the problem worse. ${ }^{13}$

This paper suggests that Weatherford is mistaken in her assumption. Volunteerism united communities and while not all voluntary efforts necessarily aided troops on the front in a tangible way, they provided those on the home front with a feeling of contribution to the war effort. After all, America did win the war and because of this simple fact, it is doubtful that volunteerism made the problems associated with the war worse.

Volunteerism created a sense of community in a time when many had recently migrated to California, it kept morale high when rationing forced Californians to do without, and provided a sense of participation for a people eager to avenge the “cowardly" attack on Pearl Harbor. Volunteerism also allowed minority groups to prove their American-ness. This paper proposes that home front volunteerism in California during World War II was of much greater importance to the war effort than traditional historical studies report, and conversely to Weatherford's thesis, it significantly aided the war effort. This paper also hopes to fill the gap in research by providing a comprehensive study of the varieties of volunteerism in California during World War II. By creating a sense of universal involvement the war was won at home and the way was paved for victory overseas.

\footnotetext{
${ }^{13}$ Weatherford, American Women and World War II, 236.
} 


\section{A LEGACY OF SERVICE: AMERICAN WARTIME VOLUNTEERISM PRIOR TO WORLD WAR II}

Before the Second World War, American volunteerism was ubiquitous in wartime. During the Revolutionary War much of the non-combat volunteerism was carried out by women. Women organized boycotts of British goods and, along with men, participated in rioting against the British enemy before and during the war. They followed the American soldiers; cooking, nursing, and laundering for the men. They were not paid for these contributions. Many followed the troops in order to support their husbands, but a significant amount were unmarried and providing their services as a voluntary way of aiding the troops. ${ }^{14}$

In the Civil War, Americans, who were not otherwise involved in combat, often volunteered their time caring for wounded soldiers. Once again, the vast majority of the voluntary burden fell upon women. Some very powerful women took part in caring for wounded soldiers including Mary Todd Lincoln. ${ }^{15}$ Not all nursing volunteers were women though; Walt Whitman volunteered as a nurse in a hospital along with many other men who did not serve in combat roles. Often these voluntary efforts were unplanned and occurred as the need arose. Martha Liggan, one such woman, found herself caring for a mortally wounded Confederate soldier, and writing a letter to his mother upon his

\footnotetext{
${ }^{14}$ Jon Butler, Becoming America: The Revolution Before 1776 (Cambridge, Massachusetts: Harvard University Press, 2000), 240. Female volunteerism is a common theme throughout American wars. Women and volunteerism on the home front are inexorably linked as will be discussed later.

${ }^{15}$ Doris Kearns Goodwin, Team of Rivals: The Political Genius of Abraham Lincoln (New York: Simon \& Schuster Paperbacks, 2005), 456-459. On page 459, Goodwin points out that unlike other "society women," who tended to the wounded and volunteered in Civil War hospitals who often were praised in newspapers, Mary Todd Lincoln received little to no credit from the media for her work with the wounded.
} 
death. ${ }^{16}$ Voluntarily caring for the wounded was not the only role played by women in an attempt to aid the war effort. Women knitted socks, sewed pants, and assembled other clothing and comfort items for sons, brothers, and fathers on the battlefield. ${ }^{17}$

During the Spanish-American War, volunteers from the American Red Cross provided home cooked food, utilizing donated supplies, to soldiers stationed at Camp Hobson in Georgia. The Red Cross Volunteers also provided aid to US soldiers stationed in war zones around the Caribbean and the Pacific. ${ }^{18}$

During World War I, volunteers on the American home-front provided aid to the troops fighting in Europe, and addressed the deadliest pandemic of the century, the Spanish Influenza. ${ }^{19}$ As a result much of the home-front voluntary effort would focus on aiding civilians suffering from the virus. When Woodrow Wilson, suggested that Americans, now imbibed with a new found patriotism, volunteer with the Red Cross in order to aid the war effort, the organization was flooded with new members and by 1918 there were $8,100,000$ volunteer members of the Red Cross. ${ }^{20}$

\footnotetext{
${ }^{16}$ Andrew Carroll, ed., War Letters: Extraordinary Correspondence from American Wars (New York: Washington Square Press, 2001), 94-96.

${ }^{17}$ Carroll, 62.

18 "The American Red Cross in the Spanish-American War" from The American Red Cross [Cited 12 May 2008]: available from http://www.redcross.org/museum/history/spanishAmWar.asp .

${ }^{19}$ The Red Cross estimates that 20-40 million people world wide died as a result of the flu pandemic. They also estimate that approximately 500,000 Americans died of the virus before it finally disappeared in 1919. Please see: "World War I Accomplishments of the American Red Cross" from The American Red Cross [Cited 12 May 2008]: available from http://www.redcross.org/museum/history/ww1a.asp .

For an excellent letter, relating the ever present horrors of the flu on the American home-front please see: John E. Bott to Harry Bott, "John E. Bott Tells His Son Harry in France with the AEF, Joyful News of a Recent "Arrival" to the Family_Followed by a Devastating Loss," in War Letters: Extraordinary Correspondence from American Wars, ed. Andrew Carroll (New York: Washington Square Press, 2001), 142-143.

20 "World War I Accomplishments of the American Red Cross" from The American Red Cross [Cited 12 May 2008]: available from http://www.redcross.org/museum/history/ww1a.asp .

The Red Cross raised over 400 million dollars in money and materials in 1918, and along with their efforts in battle zones, they aided over 500,000 families on the home front. There were 3864 local chapters in 1918, up from 107 in 1914. By 1918, along with the 8.1 million volunteer members, there were 20.39 million adult members (up from 16,708 in 1914) and 11.4 million junior members.
} 
Volunteering oneself to aid the war effort was a central theme in every American war from the American War for Independence to World War II. Volunteerism was particularly important in early American wars where the home front and the battle front often merged. Throughout American history voluntary efforts by civilians during wartime have created a sense of unity on the home front and boosted morale of both civilians and soldiers. World War II was no exception to this rule. It served as a changing point in the twentieth century it required greater human struggle and effort than had ever before been seen in the world. It unleashed untold destruction upon Europe and Asia. The awesome destructive power of the atom was harnessed for the first time. Inversely, it also became a beacon for human "greatness."

In America World War II has been largely popularized as the "good war" and the generation that fought it called "the greatest generation." 21 Those that participated in voluntary efforts were a definite part of "the greatest generation."

Wilson was also the honorary chairman of the Red Cross.

${ }^{21}$ The idea of World War II as the "good war" has been present in American thought since the beginning of the war but it was popularized by Studs Terkel's 1984 collection of oral histories, "The Good War." The idea of the "greatest generation" has also been a part of American mythos ever since the end of the war. It was popularized by Tom Brokaw's The Greatest Generation. See:

Studs Terkel, "The Good War": An Oral History of World War Two (New York: The New Press, 1984). And: Tom Brokaw, The Greatest Generation (New York: Random House, 1998). 


\section{ON THE PRECIPICE: VOLUNTEERISM IN CALIFORNIA ON THE EVE OF WORLD WAR II}

Throughout 1941, few Americans recognized that their country would soon be thrust into the bloodiest conflict in human history. With Europe and Asia already embroiled in brutal and devastating warfare, America struggled to pull itself out of the Great Depression. There were bitter divisions among Americans as to what role the United States should take in the conflict, if it took any role at all. Though political cartoonists such as Theodor Seuss Geisel attempted to awaken Americans to the threat posed by Hitler and his Axis, powerful anti-war groups such as America First successfully convinced many Americans that the country needed to focus on problems at home and leave Europe and Asia to their own devices. ${ }^{22}$ As Europe burned, many Americans took part in voluntary charitable efforts to aid less fortunate Americans. Prior to December 1941, the mass, government organized, volunteer efforts that became an important part of World War II did not exist. Instead, in the pre-war period, volunteerism mostly consisted of isolated acts of charity.

In early December, 1941 the Los Angeles Times reported on a new gift shop that had just opened in Pasadena. The Corridor Gift Shop was located on the first floor of

\footnotetext{
${ }^{22}$ Theodor Seuss Geisel (Dr. Seuss) was employed as a political cartoonist for the left-wing daily newspaper $P M$. In the months leading up to the Japanese attack on Pearl Harbor many of Seuss's cartoons warned Americans about the dangers of isolationism and implored that American's "wake up" to the threat posed by Hitler and Mussolini. For an excellent collection of Dr. Seuss' World War II political cartoons See:

Richard H. Minear, ed., Dr. Seuss Goes to War: The World War II Editorial Cartoons of Theodor Seuss Geisel (New York: The New Press, 1999).

Many prominent Californians were members of the America First movement including; publisher William Randolph Hearst, Stanford University President Ray Lyman Wilbur, actress Lillian Gish, and novelist Kathleen Norris. Former Californian and world famous pilot Charles Lindbergh served as a mouthpiece for the organization. It would collapse in the wake of the Pearl Harbor attack after being severely weakened by several anti-Semitism tinged speeches made by Lindbergh.

See:Kevin Starr, California: A History (New York: The Modern Library, 2005), 221.
} 
Huntington Memorial Hospital and devoted to charity. Those that worked in the shop were volunteers from the Huntington Memorial Clinic Auxiliary and all proceeds were used to diagnose and treat those who suffered from tumors or cancer. ${ }^{23}$ Volunteerism in the period just prior to World War II tended to focus on charitable efforts. The average American volunteered his or her time to whatever charitable acts he or she could accomplish. Joaquin Craviero, Owner of the Golden West Restaurant in San Luis Obispo, California made a habit of feeding impoverished people for free at his restaurant where he "would have that person sit at the counter rather than in the back room or outside."24

There were several organizations devoted to volunteer work in California. In the months prior to the Japanese attack on Pearl Harbor these groups conducted their charitable business as they had in previous years. Philanthropic societies such as the Crippled Children's League thrived in California in the years prior to World War II. In late January 1941 the Crippled Children's League and the Sand Diego Junior League volunteered at the Bing Crosby Open golf tournament and the invitational barbecue that followed it. ${ }^{25}$ These groups used the proceeds from this event to fund their charitable efforts in Southern California. ${ }^{26}$ The Boy Scouts of America and the Girl Scouts also conducted volunteer work throughout the state. The Los Angeles Times reported that Girl

23 “Gift Shop Innovation," The Los Angeles Times, 7 December 1941, sec. E.

${ }^{24}$ Aldora Craveiro Santos, "For Some Soldiers' Wives: Warm Meals and Money,” in Harth, Krieger, and Krieger, War Comes to the Middle Kingdom 67.

See also:Evangeline "Jean" Kirk, "Sit Down Over There," He Would Say Sternly," in Harth, Krieger, and Krieger, War Comes to the Middle Kingdom, 65.

Kirk, the daughter of Craveiro, relates a story about her father's charitable volunteerism, "When a depression era "hobo" or "tramp" - as they were called-came into the restaurant to ask for something to eat, my father would say, "Sit down over there," indicating a stool at the counter. He then would give the person a bowl of soup, two slices of French bread and coffee. This happened many times."

${ }^{25}$ The Bing Crosby Open golf tournament was first held in 1937.

${ }^{26}$ Christy Fox, "Society Starts Year in Philanthropic Key," Los Angeles Times, 5 January 1941, sec. D. 
Scouts volunteered on "practical community problems."27 Girls were trained in skills that could be effectively used in voluntary efforts. This training included; first aid, home nursing, and supplying food and clothing to the needy. Concurrently, Girl Scouts volunteered at "day nurseries" where they would entertain children and sometimes form Brownie groups. $^{28}$

As Europe fell to the Nazis and Japan gobbled up an ever increasing portion of the Pacific, the U.S. government began to plan for a potential war against the Axis. In September 1940, with the passage of the Selective Service act, America began to enlist 900,000 men each year into the armed forces as a precautionary measure. ${ }^{29}$ California played host to an influx of soldiers. The government stationed thousands of troops in the state and communities struggled to provide housing for the soldiers' families. ${ }^{30}$ The Central Coast of California suddenly found itself deluged with soldiers sent from around the nation to train at the area's newly founded military bases. Purchased by the Army in 1940, Camp San Luis Obispo became a new home for many of these soldiers. ${ }^{31}$ The sleepy community of San Luis Obispo rose to the occasion and did all that it could to aid the soldiers, many of whom were hundreds if not thousands of miles from home. The

\footnotetext{
${ }^{27}$ Bess M. Wilson, “Girl Scouts Mobilize for Community Service,” Los Angeles Times, 12 January 1941 , sec. D.

${ }^{28}$ Ibid.

The Brownie program is essentially a junior Girl Scouts for girls aged seven to ten.

${ }^{29}$ Bill Cattaneo, “Armistice Day Became Induction Day for 42” in Harth, Krieger, and Krieger, War Comes to the Middle Kingdom, 80.

${ }^{30}$ Eleanor Brown, "There was a Time when any Room Would Do," in Harth, Krieger, and Krieger, 68.

See Also: Arthur Verge, "Daily Life in Wartime California," in Lotchin ed., The Way We Really Were, 1921.

${ }^{31}$ The history of Camp San Luis Obispo actually goes back to 1928 when it was a California National Guard post named Camp Merriam. In 1940 it was leased by the Federal Government to accommodate the newly expanded $40^{\text {th }}$ infantry division. It was returned to state control following the war in 1946 only to be re-leased by the Federal Government from 1950-1965. See:

"Historic California Posts: Camp San Luis Obispo" in The California State Military Museum [cited 21 November 2008]; available from http://www.militarymuseum.org/CSLO\%20History.html
} 
Telegram-Tribune reported that by March 1941, more than 25 volunteer organizations were providing entertainment for soldiers. Among many that volunteered were groups such as the Lions, Kiwanis, and Rotary. Another group, the San Luis Obispo (S.L.O.) Exchange Club volunteered with a "take-a-soldier-home-to-dinner" project. ${ }^{32}$ The Business and Professional Women's Club of San Luis Obispo in cooperation with the county, the city, and the local American Legion post hosted dances at a local recreation hall known which came to be known as the "Soldier's Hut." 33

Of course not all volunteerism in California was focused on aiding fellow Americans. Many people recognized the stress that Europe was going through and volunteered for charitable efforts to aid the war-torn people of Europe. Refugees that had fled the Nazi war machine to California provided particularly strong support for their brethren in Europe. Ignace Paderewski, the first president of the Polish Republic, fled Poland before the war. Throughout the war he lived in San Ygnacio, a small community northwest of Paso Robles, California. Paderewski raised money for the Free Poles who had relocated to Great Britain, by hosting dances at the Paso Robles Hotel. ${ }^{34}$ One did not have to be a refugee from war-torn Europe in order to feel a strong sense of empathy towards the Europeans that were suffering because of the Axis's aggression and Americans who had never been to Europe volunteered their time to aid war victims as well.

${ }^{32}$ Stan Harth, "County Geared Up Early to Entertain Servicemen" in Harth, Krieger, and Krieger, War Comes to the Middle Kingdom, 70.

${ }^{33}$ Ibid.

${ }^{34}$ Harth, Krieger, and Krieger, War Comes to the Middle Kingdom, $\mathrm{x}$. Unfortunately, these dances ended shortly after the war began when the hotel burnt to the ground, the result of an accidental fire. Volunteer firefighters fought the blaze. (75). 
One of the ways in which Americans provided aid to the suffering in Europe and Asia was through volunteering with the Red Cross. In early January 1941, the Los Angeles chapter of the Red Cross shipped more than three and a half tons of winter clothing to England, the Netherlands and China. ${ }^{35}$ A week later, a Red Cross ship set sail for Greece with $\$ 1,176,000$ in relief supplies consisting of twelve million pounds of "foodstuffs, medical supplies, clothing, ambulances and hospital trucks." 36 Americans continued gathering goods for the Red Cross once the war began, but the focus changed to aiding American soldiers first, then war torn civilians.

In the early months of 1941, not all Americans volunteered with the zeal that existed when America entered the war. Many Americans still suffered as a result of the Great Depression. Tthere also was a strong isolationist sentiment promoted by influential America-Firsters such as Charles Lindbergh. Many of the articles devoted to voluntary efforts in the months before the United States joined the war were relegated to the latter sections in most newspapers. ${ }^{37}$ Once America joined the war, large scale voluntary efforts often garnered front page attention and served as powerful patriotic propaganda.

Unsurprisingly, some voluntary efforts before the war suffered from a lack of volunteers. The Los Angeles chapter of the Red Cross was constantly looking for volunteers to aid in their mission to help war victims overseas. A January 5, 1941 article in the Los Angeles Times reported that volunteer workers were needed to work with

35 “Clothes Sent to War Victims,” Los Angeles Times, 5 January 1941, sec. B.

The Chinese American community in California was very active in supporting China's fight against Japan. This will be discussed in depth in a later section.

36 "Vessel With Relief Supplies for Greece to Sail Next Week," Los Angeles Times, 9 January 1941, pg. 4.

Of course, this ship was filled through national effort. The Los Angeles chapter of the Red Cross certainly did its part but was not alone in providing goods for this shipment.

${ }^{37}$ For example: The article, "Clothes Sent to War Victims" appeared on B11 of the Los Angeles Times, and "Society Starts Year in Philanthropic Key" appeared on D2 of the Los Angeles Times. 
"materials and supplies to be made into the necessary garments requested by the workers in the war-torn nations." 38 Pleas such as this would continue to be mostly ignored until the United States entered the war.

The Girl Scouts also suffered from a dearth of adult volunteers in early months of 1941. As men were being drawn out of the workforce due to the newly passed Selective Service Act, more and more women were forced to abdicate traditional roles in order to go to work. This helped to carve out a new niche for women in American society but groups such as the Girl Scouts who relied on the volunteerism of housewives were forced to alter their program to fit the situation. On January 12, 1941, the Los Angeles Times reported that adult leaders were drastically needed, a Girl Scout leader quoted as saying; "One of the tragedies of our work is that we have hundreds of girls on waiting lists, girls who want to do scout work and cannot join because no leader has offered to undertake a new troop. ${ }^{, 39}$ In addition, as Californians focused more and more on aiding civilians suffering overseas, non-war related organizations, such as the Girl Scouts, struggled to meet their own volunteer quotas.

After the December 7, 1941 Japanese attack on Pearl Harbor, there was a paradigm shift in American volunteerism. No longer was volunteerism undertaken only by isolated groups in society. Volunteerism became a major concern. No longer was volunteerism only a matter of service and charity. It was now, in the minds of the people, vital to national survival. Federal, state, and local governments confirmed this view by creating organizations and programs which provided Californians and all Americans with the opportunity to volunteer and aid the war effort.

\footnotetext{
38 “Clothes Sent to War Victims,” Los Angeles Times, 5 January 1941, sec. B.

${ }^{39}$ Bess M. Wilson, "Girl Scouts Mobilize for Community Service,” Los Angeles Times, 12 January 1941, sec. D.
} 


\section{WAR COMES TO THE GOLDEN STATE: CIVIL DEFENSE VOLUNTEERISM IN THE CHAOS OF WAR}

$\sim$ Our job is to leave them [ the armed forces] free to do their job free in the knowledge that their homes and ours are protected.

It's cold these nights...up on this hotel roof watching for planes...but it kind of warms me to think I'm doing something too. It makes the waiting easier ${ }^{40}$

When the war finally came to California, it came not in the form of exploding bombs or invasion, but in the minds of the people and the government, attacks were imminent. Because the people of California feared an invasion, the methods of volunteerism chosen most enthusiastically in the early days of the war were civil defense efforts. Civil defense programs had been implemented in California as early as the beginning of 1941 but until the Japanese attack on Pearl Harbor, recruitment efforts were unsuccessful. ${ }^{41}$ Once the war started, Office of Civilian Defense (OCD) headquarters in the cities of California saw a significant increase in volunteers. In San Diego, enrollments jumped from a paltry four hundred to eighteen thousand in the first few weeks. Two weeks after the attack on Pearl Harbor, San Francisco boasted forty-five thousand recruits. By March 1942, Los Angeles had recruited eighty-three thousand volunteers into

\footnotetext{
${ }^{40}$ Excerpts from: Office of War Information, "'Yankee Doodle:' Program Number 1," 31 October 1942, box 55, RG 171, National Archives Laguna Niguel.

${ }^{41}$ Lotchin, The Bad City in the Good War, 37. The Office of Civilian Defense was directed by Mayor La Guardia of New York City. It was caught off guard by the Japanese attack on Pearl Harbor. Historian A.A. Hoehling explains in his work Home Front U.S.A. that the OCD "had set up typewriter desks, file cabinets, and the familiar governmental "organizational charts" under the assumption that the United States would first be locked in a death grip with Nazi Germany, whatever the incendiary spark. The impertinence of the Japanese had somehow not been envisioned."

A. A. Hoehling, Home Front, U.S.A. (New York: Thomas Y. Crowell Company, 1966), 34.
} 
civil defense. ${ }^{42}$ By February 1942, there were more than five million volunteers in civil defense nationwide. ${ }^{43}$

To better exploit the skills of the swarm of new volunteers the OCD set up volunteer offices in most communities. Each volunteer office had a variety of responsibilities including:

1) "Receiving applications and recruiting all volunteers for all services, and maintaining the official roster of the council."

2) "Referring volunteer candidates for civilian protection service...to that service for approval and enrollment."

3) "Referring volunteer candidates to civilian war service agencies...for approval and enrollment."

4) "Discouraging use of volunteers for non essential projects.",44

In order to better educate volunteers, the OCD volunteer office circulated a variety of educational and training films with titles such as "Air Raid Warden" and "Scrap for Victory.", 45

The fear of an invasion by the Japanese was very real in California, boosting volunteerism. The importance of civil defense was stressed throughout the state. In the event of an invasion, volunteers were to be charged with protection and care of their fellow citizens. Newspapers warned citizens not to rely solely on the Army for protection

\footnotetext{
${ }^{42}$ Lotchin, The Bad City in the Good War, 37-38.

In The Way We Really Were: The Golden State in the Second World War, Lotchin says that "In Los Angeles it was estimated that nearly one out of ten city residents was involved in some form of civilian volunteer defense by 1943.

Lotchin, The Way We Really Were, 15.

${ }^{43}$ Geoffrey Perret, Days of Sadness, Years of Triumph: The American People 1939-1945 (New York: Coward, McCann \& Geoghegan Inc., 1973), 231.

By late Summer 1942, there were ten million volunteers divided into eleven thousand Local Defense Councils nationwide (232).

${ }^{44}$ New York State War Council, Office of War Training Programs, "Block Leader Instructor's Manual: A Suggested Course for Training Block Leaders in the State of New York," 1942, box 55, RG 171, National Archives Laguna Niguel, 15.

${ }^{45}$ New York State War Council, Office of War Training Programs, "Block Leader Instructor's Manual" box 55, RG 171, National Archives Laguna Niguel, 32-33.
} 
in the event of an invasion, "the main thing to remember is that the Army is not taking care of civilians. The Army will have its hands full if there is an attack and civilian authorities have more than adequate plans to protect and care for the civilian populations. ${ }^{, 46}$ Assistant Secretary of War John J. McCloy warned Californians that the "protection of private property in California should be the primary responsibility of the state...The war department believes that the protection of instillations is a primary responsibility of operators, owners, local and state governments. ${ }^{, 47}$ As a response to the government's insistence that Americans must protect their own property, Californians joined auxiliary police units. In the city of Santa Maria, the thirty member rifle club volunteered to aid in formal civil defense in the event of an attack. ${ }^{48}$ In reality though, civil defense encompassed a variety of activities.

Those who volunteered in civil defense found themselves placed in a variety of roles. All of these volunteers earnestly undertook the duty of defending California from potential Japanese attack. In response to the wave of volunteerism, the OCD allowed volunteer civil defense organizations to determine what duties they accepted in the government's Civilian Intelligence Plan. ${ }^{49}$ In response to a glut of requests for guidance, the OCD Ninth Civilian Defense Region Southern California sector circulated a letter to

46 "Santa Barbara Boasts First Complete Evacuation Plan for Coast," Santa Barbara News-Press, 1 August 1942 , sec. A.

47 "California Not in Grave Danger, Declares Downey," Santa Maria Daily Times, 8 January 1942, pg.1.

${ }^{48}$ War Disaster Relief Plan Reports 1942-1943, Santa Maria," box 54, RG 171, National Archives Laguna Niguel.

Firearms ownership in the United States was cited by Japanese Admiral Isoroku Yamamoto as one of the reasons that the Japanese did not invade the United States following Pearl Harbor. He said "You cannot invade the mainland United States. There would be a rifle behind each blade of grass." See: "Isoroku Yamamoto Quotes" in Famous Quotes.com, [cited 27 January 2009]; available from http://www.famousquotes.com/search.php?search=1\&FirstName=Isoroku\&LastName=Yamamoto \&field= FullName.

${ }^{49}$ The Civilian Intelligence Plan essentially provided federal agencies and civilian agencies with descriptions of the methods that the Japanese may use in an attack of the west coast and how to best thwart these methods. 
all civilian run defense agencies in its jurisdiction regarding dissemination of the Civilian

Intelligence Plan and its application towards directing volunteer organizations;

...not all of the obligations suggested by the plan will be applicable to your organization...but it is important that you, and all other civilian agencies, be given a picture of the general situation here on the coast, with its varied possibilities and its imminent dangers. You will, of course, be able to discern your own duties and interests in the matter and we shall rely upon your cooperation and assistance in carrying out the purposos [sic] of the plan. ${ }^{50}$

Volunteers served as "plane spotters, air-raid wardens, ambulance drivers, blackout wardens, firefighters, and first aid providers." ${ }^{51}$ Plane spotting in particular was a volunteer activity that people of all ages participated in, even children unofficially. Spotting was equally popular among all age groups as an easy and helpful way of contributing to homeland defense. ${ }^{52}$ Even established volunteer organizations worked diligently to scan the skies for enemy aircraft. The Rotary club of Guadalupe, California manned the Guadalupe air-raid observation post so effectively that they received an award from Rotary International for their service. ${ }^{53}$ So many different people and organizations took part in spotting efforts that the California Office of Civilian Defense was inundated with incident reports prompting the release of a memo describing proper reporting procedures. It read: "the reporting of all incidents...observed by civilian personnel should be reported through the head office of the organization by which the

${ }^{50}$ Willard W. Koith, “10 November 1942,” box 45, RG 171, National Archives Laguna Niguel.

${ }^{51}$ Lotchin, The Way We Really Were, 15.

Lotchin estimates that by 1943 nearly one out of ten city residents in California volunteered in some sort of civil defense.

${ }^{52}$ Mary L. Appling, "Behind the Combat" in Women of the Homefront: World War II Recollections of 55 Americans, ed. Pauline E. Parker (Jefferson, NC: McFarland and Company inc., 2002), 208-209.

53 “Club Praised on Patriotism,” Santa Maria Daily Times, 10 January 1942, pg. 1. 
individuals are employed. These organizations will in turn report the incident to the

Sheriff of the county in which the incident occurred." 54

Organizations throughout California issued calls for volunteers. These pleas were readily answered. On December 8, 1941, Joseph F. Reed, administrative assistant to the Chief of police for Los Angeles, requested fifteen thousand civilian volunteers to form a volunteer auxiliary police force. Reed assured would-be volunteers that the program was a part of the "National Civilian Defense program." Recruits were trained in "rescue work, first-aid, demolition, decontamination, black-out policing, civilian education and other related police subjects." The recruits served as volunteers and therefore received no pay. ${ }^{55}$ Concurrently Los Angeles Fire Chief John Alderson asked for volunteer firefighters to serve as air-raid crews. The training, as explained by Alderson, included "all types of fires dealing particularly with incendiary bombs, casualties and first aid."

Expecting a rapid influx of volunteers the Los Angeles Times explained that "Sixty instructors are ready to train auxiliary firemen, 1200 weekly, in air-raid protection." ${ }^{, 56}$

These requests were filled by enthusiastic Californians looking to defend their homeland from enemy attack. Communities around California soon had active auxiliary police and fire departments. ${ }^{57}$

\footnotetext{
${ }_{55}^{54}$ Frank Royse, "3 February 1943," box 45, RG 171, National Archives Laguna Niguel.

55 "Call Issued Here for 15,000 Volunteer Auxiliary Police," Los Angeles Times, 8 December 1941, pg. 3.

${ }^{56}$ Ibid.

${ }^{57}$ Some examples include Lockwood Gardens in Oakland that had forty auxiliary police officers. See: Marilynn S. Johnson, The Second Gold Rush: Oakland and the East Bay in World War II (Berkeley: University of California Press, 1993), 123.

Santa Barbara had 125 auxiliary police officers by 1943. See: War Disaster Relief Plan Reports 1942-1943, "Santa Barbara," box 54, RG 171, National Archives Laguna Niguel.

Unincorporated Areas of Santa Barbara County had a total of 147 auxiliary police and 95 volunteer firefighters on top of 137 that had been assigned to the county by the OCD. See: War Disaster Relief Plan Reports 1942-1943, "Santa Barbara County," box 54, RG 171, National Archives.

Santa Maria had only 5 auxiliary police initially but as the war progressed the number increased to 85 . See: War Disaster Relief Plan Reports 1942-1943, “Santa Maria,” box 54, RG 171, National Archives.
} 
Civilian pilots volunteered with the Civil Air Patrol in vast numbers. In California their duties were largely centered on anti-submarine patrol. ${ }^{58}$ The vital importance of anti-submarine watch became painfully clear when the oil tanker Larry Doheny was torpedoed in mid-December and the Montebello was sunk off of Cambria, California on December 23, 1941. ${ }^{59}$ Luckily the crew of the Montebello was saved, but the ship was a complete loss. It still sits entombed in the icy water off the coast of Cambria.

Women were also called to volunteer in civil defense. Although the Office of Civilian Defense did not organize any programs specifically for women, their volunteerism was welcome. ${ }^{60}$ Just days after the war began, women rushed the Los Angeles city hall to answer the City Civilian Defense Council's call for volunteers. On December 15, 1941 more than five hundred women registered with the City Civilian Defense Council as volunteers. More than one-hundred and twenty of them requested to be assigned to the Air Raid Warning Service. According to the Los Angeles Times the only people turned away from such voluntary efforts were those that worked in "defense" or "public utilities." 61

Women in San Francisco and throughout the state volunteered for the American Women's Voluntary Services (AWVS). The main goal of the AWVS was to prepare for the bombing and invasion of American cities. ${ }^{62}$ They trained women to drive ambulances and to render first aid in the emergency situations that followed if American cities began

\footnotetext{
${ }^{58}$ Perrett, Days of Sadness, Years of Triumph, 233.

${ }^{59}$ Not only would incidents such as these add to the already jittery nerves of Californians but they would also dramatically increase anti Japanese-American sentiment eventually leading to Executive Order 9066 and Japanese Internment. See: Blum, V Was for Victory, 157.

${ }^{60}$ Yellin, Our Mothers' War, 171.

61 "Call for Feminine Volunteers Brings Rush to City Hall," Los Angeles Times, 16 December 1941, pg. 4.

${ }^{62}$ Yellin, Our Mothers' War, 172.
} 
getting bombed. ${ }^{63}$ Women in the AWVS patrolled the coast looking for enemy aircraft. ${ }^{64}$ They also learned military skills such as safe firearms handling so that they could defend the coastline in the event of an invasion. ${ }^{65}$ Nationwide, throughout the course of the war, 325,000 women volunteered with the AWVS. ${ }^{66}$ By 1942 , when it was obvious that American cities were most likely not going to be bombed, the AWVS switched its program. In California, AWVS units delivered night time "chuck wagons" to isolated soldiers and Coast Guard units stationed along the coast. They also taught Braille to soldiers blinded in combat in the Pacific at the military hospital in San Francisco. They organized emergency agricultural work and paid for the volunteer workers lodgings as well. ${ }^{67}$ A great number of women volunteered in other ways to be discussed later. In the early days of World War II women took the first steps toward the near equality of opportunity that they enjoyed in World War II by volunteering for civil defense.

Even young people joined in civil defense by participating in a variety of organizations. America Organizes to Win the War, the U.S. Government's official handbook for the American war effort, encouraged youths to enroll in one of many volunteer organizations in the United States including the Boy Scouts, the Girl Scouts, the Campfire Girls, the Girl Reserves, and the Junior Red Cross. In these organizations young people contributed to civil defense by learning a variety of skills that aided the war

\footnotetext{
${ }^{63}$ Weatherford, American Women and World War II, 233.

${ }^{64}$ This job was later taken over by the WAC according to Yellin.

${ }^{65}$ John Garvey and the California Center for Military History, San Francisco in World War II, Images of America, (San Francisco: Arcadia Publishing, 2007), 40.

${ }^{66}$ Yellin, Our Mother's War, 172.

Yellin explains that as the war dragged on and fear of cities on the home front being attacked subsided the AWVS switched it's focus and became a sort of "clearinghouse for potential volunteers." The women who volunteered with the AWVS would do such jobs as "driving ambulances, operating mobile kitchens, driving in motor pools for the military and other public and government agencies, selling war bonds, working in canteens, photography, radio work, typing, and emergency switchboard service" (172).

${ }^{67}$ Weatherford, American Women and World War II, 233.
} 
effort. They also participated in community service activities. ${ }^{68}$ The San Francisco branch of the Junior Victory Army organized a bicycle corps that provided a civilian defense messenger service. ${ }^{69}$ The OCD even created Youth Service Councils at each local OCD post. Each Youth Service Council was set up to "promote, enrich and supplement the outof-school youth activities of the community" and "to give the young people of the community an opportunity to plan and execute many of their own community activites."70 $^{, 70}$

The most notable way in which volunteers with the OCD aided the war effort in California was conducting air raid drills. The State Council of Defense in California also accepted deaf people into its ranks. It was believed that the noise of an air raid would make normal conversation impossible and therefore the ability of some deaf people to read lips would be very useful. ${ }^{71}$ Californians from the highest level of the military and government down were convinced that a Japanese air attack was imminent in the days and weeks after Pear Harbor. On the night of December 8, 1941 Lieutenant General John L. DeWitt, in charge of West Coast defense, insisted that thirty Japanese warplanes flew over San Francisco. When questioned about why bombs were not dropped he said, "Why bombs were not dropped, I do not know... It might have been better if some bombs had dropped to awaken this city.",72 One month later, Senator Sheridan Downey attempted to calm nervous Californians by saying “a 'hit-and-run attack' by enemy bombers or

${ }^{68}$ Charles H. Judd, "How Can Young People Help?," in America Organizes to Win the War: A Handbook on the American War Effort, (New York: Harcourt, Brace and Company, 1942), 312. See Also: Ronald H. Bailey, The Home Front: U.S.A. World War II, vol. 8 (Alexandria, VA: Time-Life Books, 1977), 120.

${ }^{69}$ John Garvey and the California Center for Military History, San Francisco in World War II, Images of America (San Francisco: Arcadia Publishing, 2007), 29.

${ }^{70}$ New York State War Council, “Block Leader's Instruction Manual,” box 55, RG 171, National Archives Laguna Niguel, 23.

${ }^{71}$ Breuer, The Air-Raid Warden Was A Spy, 17.

${ }^{72}$ Bailey, The Home Front, 10. 
submarines on the Pacific coast is 'possible,' but the consequences of such attacks could not be very serious."73

Yet in the early days of the war, misguided enthusiasm by air-raid volunteers sometimes turned to violence as angry mobs used fear and coercion to enforce the nightly black-outs in the cites of California. ${ }^{74}$ Fanatic patriotism and volunteerism became increasingly intertwined after Pearl Harbor. Many Californians reacted to the attacks by antagonizing Japanese Americans. These confrontations ranged from verbal taunting, to economic discrimination, to physical attacks on anyone who even appeared to be Japanese. $^{75}$ Throughout California, people of Asian lineage were targeted. This prompted Chinese American groups and the American media to launch efforts to distinguish Chinese from Japanese. On December 22, 1941, Time magazine published an article titled "How to Tell Your Friends from the Japs" as a means of enlightening Americans on the perceived cultural and physical differences between Chinese and Japanese. ${ }^{76}$ Such extreme fanaticism revealed the darker side of volunteerism. Californians' attacks on Japanese Americans helped to justify the internment of Japanese Americans for much of the war.

Though there were black-outs in almost every part of the country, nowhere did the enthusiasm of volunteers match the zeal of those in California. The infamous "Battle of Los Angeles is one such incident where enthusiasm and jittery nerves turned into

\footnotetext{
73 “California Not in Grave Danger, Declares Downey," Santa Maria Daily Times, 8 January 1942,pg. 1.

${ }^{74}$ Perrett, Days of Sadness, Years of Triumph, 231.

75 Arthur Verge, "Daily Life in Wartime California" in The Way We Really Were, Lotchin, ed., 13.

${ }^{76}$ Kevin Scott Wong, Americans First: Chinese Americans and the Second World War (Cambridge, MA: Harvard University Press, 2005), 74.

The U.S. Military made extensive efforts to prevent American Service men from confusing Chinese and Japanese peoples. Each soldier stationed in China was issued A Pocket Guide to China. This booklet contained a section titled "How to Spot a Jap." See: Wong, Americans First, 76.
} 
insanity. On the night of February 25, 1942 hundreds of anti-aircraft guns fired for hours into the Los Angeles night sky. Many civilians were injured by falling shrapnel resultant from the exploding flack missing its imaginary target and "Newspaper reporters, army officers, and scores of policemen all swore they had seen swarms of Japanese aircraft flying overhead." 77 There were no Japanese aircraft over Los Angeles that night.

Air raid drill enthusiasm continued throughout 1942. In a period of one week in August 1942, there were nine incident/air raid drills in Santa Barbara, California. Percy A. Johnson, the coordinator of the Major Disaster Emergency Council of Santa Barbara's branch of the OCD wrote: "We had 9 incident drills this past week-(they are a regular thing with us) — but all we have are rescue squads_-stretcher bearers and Ambulances (station wagons) + Doctors to advise at the scene of casualty—no fire equp' $t$ - policepublic services-etc'—. “ 78

Thomas A. Scott served as an air-raid warden during the war. Rejected from the army due to a circulatory condition in his legs, Scott felt a great sense of embarrassment because "anybody who was rejected for the service was conscious of the fact that he

\footnotetext{
${ }^{77}$ Perrett, Days of Sadness, Years of Triumph, 231-232.
}

See Also: William B. Breuer, The Air-Raid Warden Was A Spy: And Other Tales From Home-Front America in World War II (Hoboken, NJ: John Wiley \& Sons, Inc., 2003), 42.

For information on the aftermath of the Battle of Los Angeles See: "Shrapnel Rained on LA When Planes Reported," Santa Maria Daily Times, 26 February 1942, pg. 1.

In the years since the war gross overreactions such as the "Battle of Los Angeles" have become almost laughable. Even lampooned in films such as Steven Spielberg's 1941 released in 1979, at the time the events were no laughing matter. Perrett points out that "the sudden, unnecessary blackouts, the false alarms and ugly incidents were too widespread to be merely comic" adding, "Blackout accidents were beginning to take a heavy toll on life and limb." Perrett, Days of Sadness, Years of Triumph, 232.

As a result of the Battle of Los Angeles, the very next day the FBI began rounding up those in Los Angeles who were though to be subversives. There were thirty arrested of those, twenty were Japanese. This event served as a precursor of and evidence for Executive order 9066 which would place all Japanese living on the West Coast into internment camps. See: Starr, California, 222.

${ }^{78}$ Fred L. Carver, Division of Public Advice and Council to Percy A. Johnson, 10 August 1942, box 45, RG 171, National Archives.

This excerpt is was written by Johnson in the margin of the letter that he received from Carver. 
wasn't doing what other guys his age were doing." ${ }^{, 79}$ Since Scott felt a deep responsibility to aid the war effort, and prove his masculinity, he volunteered as an air-raid warden.

Once Scott volunteered as an air-raid warden he found himself entrusted with a variety of duties:

One of our responsibilities as an air raid warden was to make sure everybody had their lights turned out at night and that people weren't wandering around without any place to go. After dark, to make certain there were no lights burning anywhere, we used to climb onto the roofs to see if there were any skylights illuminated...Another of our duties was to have one or two wardens on alert at all times to watch for anything that might happen in the neighborhood-like suspicious strangers wandering around. In addition to that, of course, we had other responsibilities in the event of an air raid. ${ }^{80}$

Scott's responsibilities were fairly typical of those assigned to air raid wardens. Wardens staged mock air raid drills that Scott explains not only served as practice but also informed the general public of what air raid wardens actually did. He describes in vivid detail a drill that his post put on in April of 1942:

It covered a two-block-square neighborhood in which we had approximately eleven hundred residents... We had trucks running around throwing Fourth of July flares to imitate magnesium bombs. Then we had people pretend that they were hurt and faint. It was up to us to take care of them until a medic came along. Several thousand spectators lined the porches all around the area to watch. ${ }^{81}$ Of course not all who lived in California in World War II have such positive reflections of the duties of air raid wardens. Sheril Jankovsky Cunning grew up in Long Beach, California during World War II. He father volunteered to be an air raid warden. She can distinctly remember her father rushing out of the house with his gas mask and hard hat while she, her sister, and her mother huddled in terror in a hallway closet every

${ }^{79}$ Thomas A. Scott, “Thomas A. Scott,” in The Home Front: America During World War II, eds. Mark Jonathan Harris, Franklin D. Mitchell, and Steven J. Schechter (New York: G.P. Putnam's Sons, 1984), 65.

${ }^{80}$ Thomas A. Scott in The Home Front, eds., Harris, Mitchell, and Schechter, 65-66.

${ }^{81}$ Thomas A. Scott in The Home Front, eds., Harris, Mitchell, and Schechter, 66. 
time the air raid sirens would wail: "We couldn't help being afraid for our father. And afraid for ourselves. Our prime protector was out protecting someone else. It gave us the feeling of being abandoned." ${ }^{, 2}$ Cunning most certainly addresses the concerns and fears of many people during the war. Every time the air raid sirens wailed people huddled in fear and uncertainty of an impending attack. Many young people, like Cunning, though proud of their parents undoubtedly felt as if they were "abandoned" by those who had dutifully volunteered to participate in civil defense.

Scott and Cunning agree on the importance that volunteerism held in the war effort. Scott argues that the air raid drills had a "job for everybody" and that "everyone felt as if they were actively participating in the war effort." ${ }^{83}$ To Scott, volunteerism was the way of winning the war on the home front; "When people are up against it, they have a tendency to be more tolerant and to help each other. When you get into a crisis the humanity comes out in most of us...Everybody had certain obligations, and doggone it, they fulfilled them. ${ }^{, 84}$ Cunning reflects this sentiment; "It was a time of many dichotomies. We were taught patriotism on the one hand, distrust on the other. Although there was great fear, there was also a good feeling, a believing in our country and our government, a sense of us all pulling together." ${ }^{85}$

By volunteering with the Office of Civil Defense, many Californians' discovered a new found sense of community along with sense of contributing to the war effort. ${ }^{86}$

\footnotetext{
${ }^{82}$ Sheril Jankovsky Cunning, "Sheril Jankovsky Cunning," in The Home Front: America During World War II, eds. Mark Jonathan Harris, Franklin D. Mitchell, and Steven J. Schechter (New York: G.P. Putnam's Sons, 1984), 69.

${ }^{83}$ Thomas A Scott in The Home Front, eds., Harris, Mitchell, and Schechter, 66.

${ }^{84}$ Thomas A Scott in The Home Front, eds., Harris, Mitchell, and Schechter, 68.

${ }^{85}$ Sheril Jankovsky Cunning, The Home Front, eds., Harris, Mitchell, and Schechter, 72.

${ }^{86}$ There were groups excluded from this sense of community, most notably the Japanese, but all non-white minority groups faced special challenges during the war. Some attempted to become a part of the
} 
Historian Roger W. Lotchin explains that volunteering in civilian defense solved one of the major problems inherent in life in the modern city. Whereas the general anonymity and isolation created in the cities greatly damaged the American idea of community, volunteering in civilian defense helped to create a new sense of community. ${ }^{87}$ Rather than becoming lost in the vastness of California, migrants created communities that revolved around civil defense volunteerism. Though the bombs never fell on Los Angeles or the other communities in California, those who volunteered with the OCD were integral to the success of the war on the home front. They provided a sense of regulation in chaos and safety in dangerous times.

national community and others formed their own communities. The experience of minority groups in California will be discussed later.

${ }^{87}$ Lotchin, The Bad City in the Good War, 33.

It was not only volunteering in civilian defense that helped to create a sense of community in California during the war but all volunteer efforts. 


\section{“HIT HITLER WITH THE JUNK!": DID DONATED AUTOMOTIVE FLOOR MATS WIN THE WAR?}

The Collecting for reuse of used cooking grease and of "Tinfoil" from candy and gum wrappers, cigarette packs, etc. became second nature. I can remember the huge ball of tinfoil that my dad added to daily. The grease was taken regularly to the meat counter or the butcher shop to be used, we were told, in manufacture of munitions. Used motor oil was collected and returned to service stations and garages for recycling. ${ }^{88}$

Mary L. Appling

In the scrap collecting zeal of World War II, President Roosevelt donated the rubber floor mats from the cars at the White House. As a result of the President's action Boy Scouts flooded service stations begging passing motorists to donate their floor mats to help win the war. Coincidentally, as historian Geoffrey Perrett points out, rubber floor mats could only be recycled as additional rubber floor mats. ${ }^{89}$ Thus was the fate of many items donated by various scrap collection efforts throughout the war. Much useful scrap was collected that greatly aided the war effort, but even the drives that garnered little more than unusable junk were an essential effort towards winning the war at home.

"Junk the Axis!," "Slap the Jap with the Scrap!" and "Hit Hitler with the Junk!" are but a few of the slogans used by scrap drive organizers to whip American civilians into a patriotic scrap collecting fervor. ${ }^{90}$ Those who organized scrap drives had their work cut out for them. Shortly after Pearl Harbor, historian John Blum reports, Americans began hoarding goods due to rumors of shortages and impending rationing. ${ }^{91}$ A multi-

${ }^{88}$ Appling, "Behind the Combat" in Women of the Homefront, Parker ed., 207.

${ }^{89}$ Perrett, Days of Sadness, Years of Triumph, 234.

90 "Junk the Axis!" from: Heohling, Home Front, U.S.A., image plate

"Slap the Jap with the Scrap!" and "Hit Hitler with the Junk!" from: Perrett, Days of Sadness, Years of Triumph, 234.

${ }^{91}$ Blum, V Was For Victory, 94.

Blum expands upon the level of hoarding:

Americans began to stock up at a record rate. A study of fourteen cities showed hoarding underway in many it $4 \mathrm{ems}$ : food (especially sugar, canned meats, and vegetables, coffee, tea, 
tiered effort from the government, media, and community service groups finally

convinced apathetic Americans to part with the goods that the war effort so desperately needed. Once the effort began, however, a veritable tsunami of scrap inundated the cities of California.

By January 17, 1942 plans had already been made for the first national scrap drive. Authorities in Washington worried that the United States could fall anywhere from one million to six million tons short of 1941's steel production figures. ${ }^{92}$ The Los Angeles Times reported that this shortfall resulted from lack of scrap metal required to smelt, "the basic metal of war," steel. The government feared that not enough scrap was available in the open market which prompted an unnamed authority in the steel industry to claim: “There is only one hope for getting enough scrap to keep all the mills going somewhere near capacity for the next year, and that is to appeal to the country on a patriotic basis." Responding to this call for help, the Los Angeles Times urged citizens to "look around the cellar and attic, the barnyard and the back pasture; then you'll be ready when your local authorities tell you what to do."93

Commencing in late June and running throughout the rest of 1942, the first national scrap drive was a resounding success. From June 15 to July 2, 334,293 tons of scrap was collected nationwide, with California contributing 30,136 tons to that total. ${ }^{94}$

spices, and olive oil) rubber goods (used automobile tires, gaskets for jars, garden hoses, golf balls, galoshes, girdles), household supplies (soap, linen, furniture, blankets), clothing (particularly men's suits and shoes), and a miscellany of rifles and shotgun shells, typewriters, and paper clips. (94).

${ }_{92}^{92}$ Eighty-three Million tons.

${ }^{93}$ Frank MacMillen, "Scrap Drive May Solve Nation's Steel Problem," Los Angeles Times, 18 January 1942, sec. A.

94 “Scrap Rubber Receipts Totaled," Los Angeles Times, 7 July 1942, pg. 1.

The 1940 Census placed California's population at 6,907,387 roughly 5 percent of the national population of 132,164,569. California collected roughly 9 percent of the scrap in the 1942 scrap drive, well over its quota. See: Richard L. Forstal, ed, "Population of Counties by Decennial Census: 1900 to 1990" in U.S. 
By November, it was estimated that nearly eighty percent of American families

participated in the national scrap drive and as a result nearly three million tons of scrap

was collected from American households. When scrap collected from industry is added to that total, five million tons of scrap stood ready for use in the war effort. ${ }^{95}$ Throughout California communities did their part in the national scrap drive. The small community of Oceanside, California, located between Los Angeles and San Diego, donated eighty tons of scrap metal. ${ }^{96}$ For a city that, in 1940 , had a population of only 4,652 this is an amazing total. ${ }^{97}$

Oceanside was not the only example of exceptional volunteerism in the scrap drives in California. Throughout the state citizens and communities gave "till it hurt" and volunteered important and sometimes treasured items to the war effort. The autogiro used by Admiral Byrd on his 1936 Antarctic expedition was donated as were parts of the USS Maine that had been recovered from the harbor of Havana, Cuba. ${ }^{98}$ At nearly ninety years old, C.H. Sholes donated the iron frame from his bed and built a wooden frame to replace it. Despite his advanced age, Sholes gladly contributed to the fledgling war effort and told the Los Angeles Times: "if this awakens interest in other people to do the same

Census Bureau [cited 10 October 2008]; available from:

http://www.census.gov/population/cencounts/cal190090.txt

${ }^{95}$ George Gallup, "Survey Shows Campaign for Scrap Metal Success," Los Angeles Times, 12 November 1942, pg. 16.

96 “Oceanside Collects Eighty Tons of Scrap," Los Angeles Times, 12 November 1942, pg. 16. This total does pale in comparison to the national champion city of Peetz, Colorado. Boasting only 207 residents the city rounded up and donated 225 tons of scrap metal. See: Perrett, Days of Sadness, Years of Triumph, 234.

97 "Oceanside History," in City of Oceanside [cited 17 October 2008]: available from http://www.ci.oceanside.ca.us/datarelation.aspx?content=113 . This works out to almost thirty-five pounds per person!

${ }^{98}$ Perrett, Days of Sadness, Years of Triumph, 234. 
thing, I am honored. It strikes me that some people are not appreciative of the enormity of the situation. Delays may mean disaster."99

Throughout the state, communities recognized the severity of the situation and donated anything that could be useful as scrap. Redondo Beach, Ontario, and San Francisco, among myriad other California communities, donated the cannons that were on display in their parks and in front of veterans centers. ${ }^{100}$ The City of Los Angeles planned to collect nearly 536,000 pounds of Iron by donating "Traffic safety zone buttons and metal turning markers at intersections." The city replaced the metal markers with cement ones, perhaps proving that not all volunteerism is completely altruistic, City Traffic Engineer Ralph Dorsey explained to the Los Angeles Times that the city could actually save money by donating the signs: "the money saved by not having to paint the old style markers three times a year will pay for the exchange."101 In San Francisco, traffic violators were strongly encouraged to donate the front bumper from their automobiles in lieu of being forced to pay a cash fine, another case of not quite altruistic volunteerism. ${ }^{102}$ In Sacramento, the city council set up twenty-two bins. Painted red, white, and blue, these "Victory Bins" stood on many street corners throughout downtown Sacramento for the duration of the war. ${ }^{103}$ In Santa Maria, the Young Men's Agricultural sec. A.

99 “Nonagenarian Gives Iron Bed to Uncle Sam for Scrap,” Los Angeles Times, 17 August 1942, ${ }^{100}$ See:

“Cannon From Other Wars Donated in Redondo Drive," Los Angeles Times, 1 August 1942, pg. 8. "Ontario Gives Up Cannon in Park," Los Angeles Times, 9 October 1942, pg. 14. John Garvey, San Francisco in World War II, 28, 41.

101 "Safety Zone Buttons to Go in Scrap Drive," Los Angeles Times, 23 July, 1942, pg. 1.

${ }^{102}$ Perrett, Days of Sadness, Years of Triumph, 234.

${ }^{103}$ Geoffrey C. Ward and Ken Burns, The War: An Intimate History 1941-1945 (New York: Alfred A. Knopf, 2007), 146. 
Association collected scrap iron, old rubber tires, and paper, and offered to pick up the items if the donators simply telephoned the program coordinator. ${ }^{104}$

Unfortunately, there were some negative and unintended consequences of the scrap drives in California. In one incident that stands out as a major exception to the usual safety of volunteer efforts, a seven year old boy died after falling off of a twenty foot retaining wall that he was standing on. He was helping to sort a pile of scrap iron when he fell and fractured his skull. The Los Angeles Times lauded him as dying as a patriot. ${ }^{105}$ With his untimely death the boy became a martyr to the cause. He served as a rallying point for Californians who were being asked daily to give more and more of themselves toward fighting the war at home. Giving of one's self by patriotically sacrificing one's life to the war effort was not uncommon among the troops at the front, but on one day in September 1942, the death of a seven-year old boy from West Hollywood demonstrated that even those who died on the home front while aiding the war effort died as patriots.

Usually negativity surrounding scrap drives did not involve such tragic incidents. Garbage collectors complained that the scrap drives were hurting their businesses. One garbage collector in Los Angeles grumbled to the Los Angeles Times that there was forty percent less garbage to collect weekly than there was before the war started. This man worried not because it robbed him of all of his income but that it undermined his livelihood. In reality though, he earned money for each house that he picked up waste from and was free to sell any garbage or metal scrap collected back to the county. ${ }^{106}$

104 “Collection of Rubber, Iron Planned," Santa Maria Daily Times, 14 January 1942, pg. 2.

105 “Little Helper in Scrap Drive Dies After Fall," Los Angeles Times, 29 September 1942, pg. 8.

106 "Garbage Collector Complains Metal Drives Hurt Business," Los Angeles Times, 30 December 1942, sec. A. 
Some unscrupulous garbage and scrap collectors did not just stand idly by and protest but instead took advantage of America's scrap collecting ardor for their own profit. They collected scrap donated to them for the war effort and sold it to the government at full market price. Luckily this unpatriotic activity was not widespread and for the most part such swindles went unnoticed by the general public. ${ }^{107}$ People were just happy to be taking part in the war effort. ${ }^{108}$

All in all, the scrap drives of World War II collected a large variety of useful material, and a bunch of useless junk. The 1,700 spittoon mats donated from the United States Congress were all but useless as military material. ${ }^{109}$ A significant amount of the aluminum collected in 1941 proved nearly impossible to recycle into material useful for aircraft construction. Though, statistically, much of the scrap collected would not directly aid the war effort in a tangible, quantifiable way, the volunteerism evident in scrap drives helped to win the war on the home front and paved the way for victory overseas. Volunteering in scrap drives created a sense of community and teamwork. As stated by Arthur Upham Pope, in his 1942 essay "Healthy Morale in Wartime," teamwork is of utmost importance, "first, teamwork gets things done, as everybody knows; and, second, it builds morale as almost nothing else will." ${ }^{110}$ Even more so, collecting of scrap became

${ }^{107}$ Perrett, Days of Sadness Years of Triumph, 234.

${ }^{108}$ Many companies and people profited off of the war effort. The Gimbel brothers, owners of eleven department stores on the East Coast, anticipated shortages as the war began. Bernard Gimbel borrowed \$21 million to build up his inventory shortly after the war began. Through 1943 the Gimbel brother's stores were able to sell nylon and silk hose at a premium since they were the only ones that had such items in stock. The Coca-Cola company saw incredible growth during the war. Robert W. Woodruff, persuaded the Army and Navy that Coca-Cola was an essential product for the soldiers because it "suited the wants of soldiers and sailors." Philip K. Wrigley of Wrigley's Gum profited off of the war, in much the same way. For more on those whom profited off of the war see: Blum, V Was for Victory, 105-116.

${ }_{109}$ Perrett, Days of Sadness Years of Triumph, 234. 257.

${ }^{110}$ Arthur Upham Pope, "Healthy Morale in Wartime" in America Organizes to Win the War, 
an all encompassing fact of life in war time California. It constantly reminded those on the home front that there was a war going on and that sacrifice was necessary for victory. 


\section{TO EVERY HOME A GARDEN AND TO EVERY SOLDIER A LETTER: VICTORY GARDENS AND LETTERS TO THE FRONT, PUBLICLY INITIATED VOLUNTEERISM IN WORLD WAR II CALIFORNIA}

As America became embroiled in the second global conflict of the century, across the nation Americans rushed to plant Victory Gardens. Initially the federal government's Department of Agriculture frowned upon the prospect of winning the war with "radishy Victory Gardens," but even they eventually embraced the gardens as a way of uniting the civilian population under a common goal. ${ }^{111}$ Once embraced by the government, the OCD began to promote Victory Gardens intensely. The California OCD presented a fifteen minute weekly radio program that began "with victory garden leaders throughout the Region" giving "authoritative information on gardening, partly through answering questions raised in letters received by State Agriculture Extension Service Directors." ${ }^{112}$ The OCD Regional Office Victory Garden program also provided copies of films from England that discussed the importance of Victory Gardens and how to maintain them. In addition it provided funds for schools and other educational institutions to instruct the public in proper care of Victory Gardens. ${ }^{113}$ By growing Victory Gardens Californians both supplemented their own allotted rations and donated surplus vegetables to the war effort.

As of April 1942, there were more than six million people nationwide growing Victory Gardens with hopes for a total of eighteen million gardens by the end of the

\footnotetext{
${ }^{111}$ Perrett, Days of Sadness Years of Triumph, 234.

${ }^{112}$ Ninth Civilian Defense Region, "Victory Gardens," Summary of Civilian War Services Staff Conference No. 8, box 55, RG 171, National Archives.

${ }^{113}$ Ibid.
} 
year. ${ }^{114}$ One year later, March 1943, there were twenty-one million families growing Victory Gardens covering nearly seven million acres of land. In 1943, Victory Gardens produced only four million tons of produce less than professional farms, a staggering statistic considering that two years before Victory Gardens were all but nonexistent. ${ }^{115}$ Across California Victory Gardens sprung up and were tended by civilians eager to do their part in the war effort. The community of Laguna Honda in the San Francisco Bay Area started its own Victory Garden project. By October 1943, the community had planted nearly three hundred family garden plots. ${ }^{116}$ Sheril Jankovsky Cunning recalled her family's effort in growing a Victory Garden during the war, "We had the most miserable, hard-as-cement, three-by-five-foot plot of ground, and grew radishes and carrots as our contributions to the war. But radishes weren't anybody's mainstay, and our carrots never got any bigger than an inch. Yet we all wanted to do our part for the war." 117 The most notable factor according to Cunning was even though her family's garden was not particularly successful, at least they tried. The planting of Victory Gardens allowed a family, such as Cunning's, to feel intimately involved in the war effort. Civilians that grew Victory Gardens had an outlet for their patriotism and a means to keep their morale high even when the war was progressing poorly.

Victory Gardens were widespread in California and throughout the rest of the United States. Luckily for Californians, the temperate climate of much of the state allowed for year around Victory Garden cultivation. Nearly every household volunteered by growing vegetables both to supplement their own allotment of food but also to donate

${ }^{114}$ Perrett, Days of Sadness, Years of Triumph, 235.

${ }^{115}$ Weatherford, American Women and World War II, 226.

${ }^{116}$ Garvey, San Francisco in World War II, 65.

${ }^{117}$ Sheril Jankovsky Cunning in The Homefront, Harris, Mitchell, and Schechter eds., 70. My emphasis. 
to the war effort. ${ }^{118}$ Everywhere there was open space Victory Gardens were cultivated. Golden Gate Park in San Francisco became an enormous communally operated Victory Garden as did most of the public spaces in California. ${ }^{119}$ Even young people participated in growing Victory Gardens, particularly in rural areas. ${ }^{120}$ Santa Maria High School, in cooperation with other local schools, planted a "Food-For-Freedom-Garden" on a three acre tract of land near the school. Students provided all of the labor for its construction, care, and cultivation. ${ }^{121}$ Almost instantaneously Victory Gardens appeared on every available plot of land. Though not all of the vegetables grown in these gardens were useful to the war effort, many were. The Victory Garden projects provided a means of community building and created a sense of involvement in the war effort. By growing a Victory Garden, a Californian family could play an active role in fighting the war from the home front.

Though "radishy victory gardens" improved morale at home, they did little to raise the spirits of the soldiers fighting overseas. Mail from home played a significant role in keeping morale high among American soldiers. Californians participated in the war effort by writing letters and sending care packages to soldiers serving overseas. From the start of the war most of those who had family serving overseas maintained active correspondence. As the war progressed there were many who volunteered to write letters and assemble care packages for soldiers that they may never have even met. During the war, the amount of mail sent overseas by Americans increased by 513 percent. The bulk of this mail was sent via V-mail film which was delivered to soldiers in the form of a four

\footnotetext{
${ }^{118}$ Lotchin, The Way We Really Were, 23.

119 Garvey, San Francisco in World War II, 59.

${ }^{120}$ Charles H. Judd, "How Young People Can Help" in America Organizes to Win the War, 317.

121 "High School to Plant Garden," Santa Maria Daily Times, 12 February 1942, pg. 1.
} 
by five and one-half inch photograph. More than one billion V-mail letters were sent from the home front during the war. ${ }^{122}$ Teenage girls in particular devoted much time in writing to soldiers. In 1944, Dorothy Heath Clary was chosen as the "girl next door pinup" of the USS Swordfish. As a result she began to receive letters from soldiers all over the world. She strove to respond to each of these letters. By early 1945 she received so many letters that writing the responses became a nearly full-time occupation. ${ }^{123}$ Across the country there were other examples of such women who would volunteer all of their spare time to answering correspondence from soldiers.

Though heavily promoted by the government, the V-mail project was successful because of 'bottom-up' voluntary efforts. What began with family members sending letters to loved ones overseas rapidly expanded into vast mailing campaigns that hoped to ensure that every soldier would at least at some time receive a letter from the home front. Soldiers' names were passed around and exchanged in volunteer groups in order to encourage more correspondence between the home front and theatres of war. Such casual letters usually contained "news of dances, movies, and popular songs." "24 American churches extolled their followers to remember that "Morale is mail." ${ }^{125}$ Church groups began to send newsletters informing parishioners serving overseas of church and

\footnotetext{
122 Judy Barrett Litoff and David C. Smith, Since You Went Away: World War II Letters from American Women on the Home Front (New York: Oxford University Press, 1991), 122-123.

Litoff and Smith explain that by converting letters written on a specially designed $81 / 2$ by 11 inch stationary to 4 by $51 / 2$ inch photographs, a collection of letters formerly weighing 2,575 pounds could be reduced to 45 pounds. Litoff and Smith also explain that the process for producing V-Mail became the basis of the microfilming process.

See Also: Ward Burns, The War, 121.

${ }^{123}$ Judy Barrett Litoff and David C. Smith, ed., Since You Went Away: World War II Letters from American Women on the Home Front (New York: Oxford University Press, 1991), 133.

Clary was a student at Southern Methodist University and not a Californian. Though not from California, she set an example for many women in California. Clary is but one of many young women whom wrote letters to many soldiers as a way of improving morale.

${ }^{124}$ Littoff and Smith, Since You Went Away, 205.

125 Gerald L. Sittser, A Cautious Patriotism: The American Churches and the Second World War (Chapel Hill: The University of North Carolina Press, 1997), 147.
} 
community news. ${ }^{126}$ Schools across California encouraged children to write letters to soldiers stationed overseas. Some elementary schools even printed newsletters to be sent to alumni soldiers. Many teachers, in particular, prolifically penned letters to former students to ensure that they did not "come away from "mail call' empty-handed.",127

Californian civilians sent gifts and care packages to those fighting overseas. Many communities took part in the national "Victory Book Campaign" that sought to collect ten million books to send overseas. ${ }^{128}$ Churches played a major role in nongovernmental promotion of such programs. For churches the stakes were doubly high, not only were they trying to raise morale for soldiers and civilians through such programs but they were also fighting to save souls. That is why it is not surprising that Churches sent Bibles and other religious materials to soldiers stationed overseas. The American Bible Society alone sent over $3,700,000$ scriptural books to chaplains overseas to distribute to soldiers. ${ }^{129}$ In addition, the religious magazine Moody Monthly was also distributed to servicemen stationed at the front. ${ }^{130}$

${ }^{126}$ Sittser, A Cautious Patriotism, 147.

${ }^{127}$ Litoff and Smith, Since You Went Away, 137.

${ }^{128}$ Santa Maria, California collected two thousand books. The Junior Red Cross set up bins in the local library, business district, and all local schools. See: "Campaign Opens for Books for Servicemen," Santa Maria Daily Times, 19 January 1942, pg. 1.

${ }^{129}$ Sittser, A Cautious Patriotism, 148. Sittser says, "In 1944 the American Bible Society gave 400,000 Bibles, 1,800,000 New Testaments, and $1,500,000$ Scripture portions to chaplains for distribution to servicemen." This group was not alone, "in 1944 the National Lutheran Council sent 4,240,000 tracts and devotionals, 188,500 Service Prayer Books, and 125,000 copies of the Army and Navy Service Book" (148).

${ }^{130}$ Sittser, A Cautious Patriotism, 149. 


\section{A TRADITION OF VOLUNTEERISM: THE RED CROSS}

The Red Cross played an integral role in providing aid to American soldiers. Founded by famous Civil War nurse Clara Barton in 1881, the American Red Cross, by World War II, had become America's most recognizable and influential volunteer organization. It became so influential that it was called the "big sister to the Army." 131 The Red Cross was also one of the most popular organizations with which to volunteer. Even small communities had active branches of the Red Cross, Santa Maria, in March 1942, boasted over four thousand Red Cross members from a total population of only ten thousand. ${ }^{132}$ One of the major projects undertaken by Red Cross volunteers was soliciting funds to provide humanitarian aid to bomb victims overseas. Just days after America entered the war, Red Cross agents canvassed California seeking \$2,500,000 in funds to aid victims of Japanese bombing. They hoped to collect $\$ 50,000,000$ total nationwide. $^{133}$

Thousands of Californians volunteered to aid the Red Cross's fundraising effort. Esther Burgard answered the Red Cross's call for volunteers and with the aid of her young son and some of the ladies from her church, she covered a large area of North Long Beach. Her experience collecting donations shows that Californians did not just selfishly aid American troops in voluntary efforts but their fellow civilians from war-torn nations as well. She said; "We had very few people who would not donate. Even when a

${ }^{131}$ Weatherford, American Women and World War II, 231.

Throughout the war, the Red Cross consisted primarily of female volunteers.

132 "Ray Hoey Heads Red Cross Work for Coming Year," Santa Maria Daily Times, 6 March 1942, pg. 1.

Population total from: War Disaster Relief Plan Reports 1942-1943, "Santa Maria," box 54, RG 171, National Archives.

133 "Red Cross Will Launch Drive," Los Angeles Times, 16 December 1941, sec. A. 
woman's husband had donated someplace else, usually she would want to donate too. Everyone gave according to their means." "134 Such was the demand for Red Cross volunteers that from the moment America entered the war the Los Angeles chapter operated its offices on a twenty four hour basis. ${ }^{135}$ The Red Cross eventually raised the funds it sought in its drive. The money was used for nursing, medicine, food, shelter and clothing for the victims of Japanese bombings at Pearl Harbor and Manila.

Volunteers in the first major Red Cross project of the war did not solely collect money. The Los Angeles Times reported that volunteers also furnished the use of their cars, studied to become nurses, served in hospitals, and taught courses in first aid and nutrition. ${ }^{136}$ This was the pattern followed by Red Cross volunteers throughout the war. Californians, as demonstrated by Esther Burgard's testimony, used the Red Cross fundraising drives as a method of showing one's support for the war effort. In turn such programs served to raise morale and helped to win the war on the home front.

The Red Cross did much more for the war effort than just raise money. Its primary focus was providing aid to civilians and wounded soldiers but it also sought to help all American soldiers. Red Cross volunteers played a vital role in providing comfort and friendliness to soldiers being shipped out of to the Pacific theatre. Between 1942 and 1945, one million soldiers were processed through Camp Stoneman in the San Francisco Bay Area. Red Cross volunteers at camp staging areas handed out coffee and doughnuts daily to soldiers awaiting deployment. On a single day in 1945, Red Cross volunteers in San Francisco distributed one thousand gallons of coffee and thirty-four thousand

\footnotetext{
${ }^{134}$ Esther Burgard, "Esther Burgard" in Harris, Mitchell, and Schechter, The Home Front, 75.

135 "Red Cross Here on 24 Hour Basis as Volunteers Sought," Los Angeles Times, 9 December 1941,pg. 13.

136 “Posters Put up For Red Cross," Los Angeles Times, 15 January 1942, sec. A.
} 
doughnuts. ${ }^{137}$ Likewise, wounded soldiers returning from the Pacific theatre usually spent at least their first few days home at a military hospital. Red Cross volunteers staffed these hospitals as aides. Eleanor Soule Crosby was one such volunteer. Working at Dante Annex hospital in the Bay Area she set up entertainment for wounded soldiers that included evening shows and films. ${ }^{138}$

Women played an extremely important role in Red Cross home front activities. By the end of the war more than 3,500,000 women, across the nation, volunteered with some branch of the Red Cross. In North Beach, California alone, the local Red Cross center was staffed by fifty women on a daily basis. ${ }^{139}$ The two most significant branches of the Red Cross were the Nurse's Aides and the Grey Ladies. These groups volunteered in military hospitals. They served as aides to medical personnel and provided a general morale boost to wounded soldiers. ${ }^{140}$ Of course this work was not always glamorous, as Mae Opal Miller, a typical Red Cross volunteer, discovered. In a letter to a friend serving up overseas she said;

In regard to the Red Cross course I'm taking. Do you know what we will be when we get thru and are eligible for our caps?...We won't be assistants to the graduate nurses, oh no, we'll be assistants to the student nurses. I'll have to do away with the long fingernails... We have to furnish our own uniforms, buy nurse's shoes and get a watch with a second hand. We got our uniforms the other night, and you should see them. Heavy blue denim, the smallest size is about 3 sizes too large. What a sloppy looking piece I'm going to be. The patients will take one look at me and have a relapse. ${ }^{141}$

${ }^{137}$ See:Starr, California, 229. and

Kevin Starr, Embattled Dreams: California in War and Peace 1940-1950 (Oxford: Oxford University Press, 2002), 78.

${ }^{138}$ Eleanor Soule Crosby, "Two Years in the Red Cross" in Women of the Homefront, Parker ed., 147.

${ }^{139}$ Gary. Mormino and George E. Pozzetta, "Ethnics at War: Italian Americans in California during World War II," in Lotchin, ed., The Way We Really Were, 153.

${ }^{140}$ Yellin, Our Mothers' War, 168. Smith, 209.

${ }^{141}$ Mabel Opal Miller to Ivan Johnson, 14 June 1944, in Since You Went Away, eds. Litoff and 
Women of California volunteered with the Red Cross and provided soldiers with safe, friendly activities and entertainment. Red Cross volunteers organized dances and beach parties, and played pool and ping-pong with soldiers on leave. The Red Cross Home Service division sent over 42 million messages to soldiers notifying those serving in the military of important news from home such as births and weddings. Conversely the Home Service division also notified families of the status of any of their loved ones who were injured and in a military hospital overseas. ${ }^{142}$ Those that volunteered with the Red Cross Home Service division were vital to the war effort on the home front. By providing soldiers with information about their families and hometowns this program and its volunteers, much like the letter writers mentioned above, helped to strengthen military morale. Although these efforts did not provide soldiers with weapons or supplies to use against America's enemies, they created and promoted a positive mental attitude among American soldiers. This ensured that the soldiers retained the high morale needed to cope with the violence, danger, and brutality of war.

Donations of blood and plasma were another tangible way that Red Cross volunteers aided the war effort. People nationwide donated blood to the Red Cross and blood donated by those living in western states such as California was doubly important as it could be promptly and quickly processed, packaged, and sent to hospitals and aid stations close to the battle fronts in the Pacific theatre. After bloody battles such as, Iwo Jima, hospital ships full of wounded arrived in San Francisco and San Diego. Thousands of Californians “jammed the donor centers to help" in response to the Red Cross' calls for blood donations. ${ }^{143}$ Even small communities did their part. Twenty members of the

\footnotetext{
${ }^{142}$ Yellin, Our Mothers' War, 168.

${ }^{143}$ Lotchin, The Bad City in the Good War, 21.
} 
Santa Maria Junior Chamber of Commerce volunteered to be on constant call at the local hospital as a precaution should an emergency arise in which blood donation was needed. ${ }^{144}$

By mid-war it took less than forty eight hours for donated blood to reach soldiers all over the world. In total 13 million pints of blood were collected by the Red Cross during the war. ${ }^{145}$ Blood donation provided those on the home front in California with a substantial way of aiding the war effort. Blood donations can be confirmed to have saved the lives of tens of thousands of American soldiers, men who would have died of their injuries. It improved morale to know that if one was wounded at least blood was on hand if necessary. General Eisenhower understood the importance of donated blood and lauded Americans for their efforts. He said: "If I could reach all of America-there is one thing I would like to do- -thank them for blood plasma and for whole blood. It has been a tremendous thing.",146

Red Cross volunteers participated by fabricating clothing and bandages to aid and comfort the troops. Of the 3.5 million women who volunteered for Red Cross duty, many found themselves participating in activities such as knitting afghans and rolling bandages. ${ }^{147}$ Others knit socks, helmet liners, and scarves for the troops. Mary L. Appling volunteered with the Oakdale Red Cross and knitted "the long, heavy, wool socks" worn by soldiers throughout the war. ${ }^{148}$ Volunteer organizations across the state participated in Red Cross sewing drives. In Santa Maria, the Jewish Council and the Junior Community

144 “Donors of Blood Organize for War Aid," Santa Maria Daily Times, 22 January 1942, pg. 1.

145 Yellin, Our Mothers' War, 168.

146 Yellin, Our Mothers' War, 168.

${ }^{147}$ Mary Elizabeth Dahl Jorgensen in Women of the Homefront, Parker, ed., 138.

${ }^{148}$ Appling, "Behind the Combat" in Women of the Homefront, Parker, ed., 207. 
Club both sewed garments for the Red Cross. ${ }^{149}$ Though, as mentioned earlier, the Red Cross provided some basic entertainment to wounded soldiers, its primary focus was health. The newly formed United Service Organizations took up the bulk of entertainment duties throughout the war, and much like the Red Cross, it relied heavily on the volunteerism of Californians.

149 “Jewish Council Meeting," Santa Maria Daily Times, 5 January 1942, pg. 3. And: “Sew for Red Cross," Santa Maria Daily Times, 5 January 1942, pg. 3. 


\section{HOLLYWOOD JOINS THE BATTLE, BUT EVEN YOU CAN ENTERTAIN THE TROOPS: CELEBRITIES, CIVILIANS, THE USO, AND VOLUNTEERISM}

From the beginning of American involvement in the war, Hollywood stepped up and aided the war effort through acts of volunteerism. Much of this volunteerism was arranged by the United Service Organizations (USO). USO volunteerism was not just limited to Hollywood celebrities, average Californians also volunteered. Both joined the USO to entertain troops awaiting deployment throughout California. Hollywood would also aid the war effort by making films that promoted volunteerism and patriotism to the general public.

The United States government's propaganda agency, the Office of War Information (OWI), played a major role in working with Hollywood to create movies that supported the American war effort. Unlike some other American wars, Hollywood did not need much convincing in order to cooperate with the OWI. Hollywood fought the war from home with a passion unprecedented for the film industry. It did its best to comply with OWI suggestions and the OWI found that it did not need to coerce filmmakers to fill their films with patriotic themes.

Of course, Hollywood did not always cooperate with the OWI completely. The OWI asked film producers to improve the image of African Americans in their films because it felt that traditional portrayals of African Americans hurt African American morale and undermined the war effort. ${ }^{150}$ Hollywood responded by eliminating most roles for African Americans in its films. ${ }^{151}$

${ }^{150}$ Clayton R. Koppes and Gregory D. Black, Hollywood Goes to War: How Politics, Profits, and Propaganda Shaped World War II Movies (New York: The Free Press, 1987), 179. 
Many of the movies made during World War II were engorged with morale building propaganda; “A marine, having just dispatched a hoard of treacherous Japanese attackers, pauses to utter a paean to democracy. A young mother, newly widowed when her husband was killed in combat, chokes back the tears and tells her infant son that daddy died so he could have a better future. A Norwegian town rises up as one against Nazi terror." 152 As the war drew to a close, the Hollywood propaganda machine injected films with a patriotism that reflected reality. In 1945's Anchors Aweigh, sailors Joe (Gene Kelley) and Clarence (Frank Sinatra) are recruited by a police officer to convince a young boy, who has run away from home, that he is too young to join the Navy. The patriotism of this child and his idolization of Joe and Clarence are reflective of the feelings of many young people during the war.

Films made in Hollywood during the war showed civilians the proper way to support the war effort from home. ${ }^{153}$ Protagonists in films produced during the war often identified with large organizations and patriotic causes. In addition they were also careful to stress class unity. ${ }^{154}$ Hollywood attempted to convince Americans that society's social problems were easily solvable because they were simply the result of individual

See Also: Linda Harris Mehr, "The Way We Thought We Were: Images in World War II Films" in Lotchin, ed., The Way We Really Were, 37.

${ }^{151}$ Mehr, "The Way We Thought We Were," in Lotchin, ed., The Way We Really Were, 37.

${ }^{152}$ Koppes and Black, Hollywood Goes to War, vii.

Films were heavily influential to public morale during World War II. The general public flocked to movie theaters as a means of escape and relaxation. Yearly, during the War, films produced profits one and onethird times better than the best year of the depression.

See: Erenberg and Hirsch, eds., The War in American Culture, 74.

${ }^{153}$ Hollywood studios went to great lengths to show Americans how to participate in the war effort. "The studios willingly complied...that movies show everybody cheerfully doing his or her bit for the war. Films showed citizens making little sacrifices without complaint—buying bonds, donating blood, volunteering for the Red Cross, putting up with rationing. And even a cinematic staple as screeching tires was toned down in Preston Sturges's The Miracle of Morgan's Creek." See: Koppes and Black, Hollywood Goes to War, 143.

${ }^{154}$ Erenberg and Hirsch, eds., The War in American Culture, 72. 
deficiency ${ }^{155}$ Films that stressed home front volunteerism showed Californians what was expected of them and glorified volunteerism and patriotism. These films kept morale high throughout the war. As historian Kevin Starr states; Hollywood "helped mobilize an entire nation" and "experienced a power even greater than it had known in the Depression." 156

The film industry did its fair share to promote volunteerism and patriotism yet it was still a business. ${ }^{157}$ Hollywood's primary concern was pleasing the public. ${ }^{158}$ Though giving full cooperation to the OWI can be considered a volunteerism of sorts it is highly likely that if the film industry did not cooperate, the OWI would have forced the issue much as it did in World War I. A great volunteeristic trend cannot be drawn out of the Hollywood studios in World War II other than the fact that their films promoted volunteerism among the general public.

Nearly everything an American viewed or read promoted volunteerism, from films to magazines to Comics. Comic books became one of the primary methods of promoting volunteerism in young people. Many of the more realistic comic books dramatized the battles overseas and were used by children as a way to keep in touch with the war all the while promoting volunteerism at home. ${ }^{159}$ Superheroes such as Superman and Captain America actively fought the Nazis and the Japanese in their comics. They encouraged children to participate in local voluntary efforts such as scrap drives and

${ }^{155}$ Koppes and Black, Hollywood Goes to War, 184.

${ }^{156}$ Kevin Starr, Embattled Dreams, ix.

${ }^{157}$ In 1941 the average weekly attendance at theaters in the United States was approximately 85 million. The Department of Commerce estimated that about 80 percent of the money spent on entertainment by Americans was spent attending motion pictures. Films would grow in popularity throughout the war. See: Linda Harris Mehr, "The Way We Thought We Were: Images in World War II Films," in The Way We Really Were, Lotchin, ed., 31.

${ }^{158}$ Mehr, "The Way We Thought We Were," in The Way We Really Were, Lotchin, ed., 30.

${ }^{159}$ Ward and Burns, The War, 122. 
paper drives. ${ }^{160}$ Captain America even encouraged children to forego joining the Captain America fan club so that they could instead donate the dime to the war effort. ${ }^{161}$ Most of the writers and creators of comic books had Jewish backgrounds. Many had family members persecuted and murdered as the Nazis' swept across Europe. ${ }^{162}$ These writers were motivated to promote the war effort in America by the plight of their families in Europe.

Before the USO was founded, Hollywood celebrities stepped up on their own and gave their time and fame to aid the war effort on the home front. ${ }^{163}$ Even before the United States entered the war, California celebrities volunteered their time to help the victims of war overseas. In January 1941, Bob Hope hosted a weekend gathering at his ranch near Palm Springs to teach British war refugee children about the American "Wild West." This event included a rodeo which was a completely new experience to Hope's young guests. ${ }^{164}$ Hollywood was instrumental in selling war bonds and promoting other fundraising activities throughout the war. Hedy Lamarr sold kisses for $\$ 25,000$ apiece at

\footnotetext{
${ }^{160}$ Encouragement to donate old comic books to paper drives in comic books is one of the reasons that Comics from the pre-War and World War II periods are so rare and so valuable among comic collectors.

${ }^{161}$ Comic Book Superheroes Unmasked, prod. and dir. The History Channel, 59 min., 2003, television program.

Efforts such as this would convince children across America to buy more than one billion dollars of war stamps and bonds throughout the duration of the war.

See: Ronald H. Bailey, The Home Front: U.S.A., vol. 8 of World War II (Alexandria, VA: Time-Life Books, 1977), 122.

162 George Cotkin, 31 January 2009.

${ }^{163}$ Celebrities would also travel overseas with the USO. Several big name celebrities left the safety of Hollywood and served in combat during the War. Gene Autry served as a Flight Officer in Air Transport Command from 1942-1946. Clark Gable who was beyond draft age at the start of the war nevertheless enlisted as a private and worked his way up to captain in the US Army Air Corps. James Stewart served in the US Army Air Corps. See:

"They Also Served: Actors With WWII Military Records," in Combat! [cited 24 November 2008]; available from http://www.jodavidsmeyer.com/combat/military/actors_in_wwii.html See Also: Nigel Fountain, ed., WWII: The People's Story (Pleasantville, NY: Reader's Digest, 2003), 226227.

See Also: Breuer, The Air-Raid Warden Was A Spy, 89-90.

164 "War Refugee Children See Wild West for Themselves,” Los Angeles Times, 6 January 1941, sec. A.
} 
one event and singer Kate Smith raised $\$ 40$ million during the course of a sixteen hour radio broadcast. ${ }^{165}$

Throughout the duration of the war most celebrity volunteerism took place through the USO. The USO was founded as the result of a meeting between head of the Federal Security Agency Paul V. McNutt, President Roosevelt, and several top military advisors. A federally administered collection of volunteer groups, its founding groups included; the Young Men's Christian Association (YMCA), the National Catholic Community Service, the Young Women's Christian Association, the National Jewish Welfare Board, and the Salvation Army. ${ }^{166}$ The USO's purpose was to entertain and comfort the troops. The importance of entertainment to the war effort is evident in 1942's official handbook for the American war effort, America Organizes to Win the War, "There are organizations devoted entirely to entertaining the armed forces. They are morale builders. And the soldiers sing. A singing army is the right kind of army. When it no longer sings, its morale is low, its fighting spirit is weak. Work, hard work; exercise and play; song and laughter-these are an unbeatable combination." ${ }^{167}$ By 1942 the USO's budget of donated funds surpassed $\$ 32$ million and by the end of the war the USO claimed that its entertainment troupes put on 428,521 live shows for over 200 million soldiers around the world. ${ }^{168}$

${ }^{165}$ Ward and Burns, The War, 90 and 92.

Hollywood celebrities were not the only group of people raising money for the war effort. State wide many volunteer groups purchased war bonds, and many banks sold them. In the month after Pearl Harbor, sales of defense bonds rose tenfold. See: "Sale of Defense Bonds Rises Rapidly," Santa Maria Daily Times, 6 January 1942, pg. 2.

${ }^{166}$ Hoehling, Home Front, U.S.A., 127.

${ }^{167}$ Pope, "Healthy Morale in War Time," in America Organizes to Win the War, 262.

168 \$32 Million donated budget from: Weatherford, American Women and World War II, 231. Performance count and Audience count from: Arthur Verge, "Daily Life in Wartime California" in The Way We Really Were, Roger Lotchin ed., 25. 
The Hollywood Canteen was the most famous and significant USO center in California. Opened in October 1942, it was the result of a campaign by film stars Bette Davis and John Garfield to turn an abandoned building near Sunset Drive in Hollywood into a place that could accommodate soldiers on leave in the Los Angeles area. ${ }^{169}$ Among soldiers in California, the Hollywood Canteen quickly became known as a place where one could "dance with a Hollywood starlet." ${ }^{170}$ Actresses such as Hedy Lamarr, Marlene Dietrich, Rita Hayworth, and Betty Grable frequented the club but made up only a small proportion of its volunteer force. With a paid staff of only nine, the Hollywood Canteen required a force of hundreds of volunteers to maintain operations. Over the course of the war, thanks to the efforts of volunteers, the Hollywood Canteen provided service to more than three million soldiers. ${ }^{171}$ The staff of the Hollywood Canteen was not solely made up of celebrities. In order for the USO to provide services to servicemen and women throughout California, it had to rely on volunteerism from ordinary citizens as well.

Doris Weatherford states the integral role that ordinary civilians played in ensuring the success of the USO, although it "became known for its recruitment of star entertainers for the troops, most volunteers spent their time on the more routine activities

Though it is out of the scope of this paper to discuss celebrities who ventured overseas to entertain the troops they are still noteworthy group. USO efforts to get celebrities to venture overseas to entertain troops began with Laurel and Hardy. After the success of that tour, the USO petitioned a number of other actors as the USO's production supervisor, Bert Wishnew, said "no one possessed a heart so cold as to say no to the USO." Notable celebrities who traveled with the USO overseas during World War II include;

"singers Bing Crosby and Frank Sinatra, dancers Fred Astaire and Ginger Rogers, actors Humphrey Bogard and Jimmy Cagney. Joan Crawford, Linda Darnell, Marlene Dietrich, Jinx Falkenberg, and Rita Hayworth also helped keep the boys' minds off the war. Aging Al Jolson traveld the world over, as did Errol Flynn, Spencer Tracy, and the man who immortalized Frankenstein, Boris Karloff. Keenan Wynn tore up a season's personal production plans to volunteer, and suave Adolphe Menjou spent a solid six months in the camps and foxholes of North Africa." Perhaps the most prolific Celebrity volunteer was Bob Hope who traveled to so many front line locations that it prompted sentries posted along the front lines to quip "Don't shoot. It might be Bob Hope!"

See: Hoehling, Home Front, U.S.A., 128-129.

${ }_{169}$ Starr, California, 231.

${ }^{170}$ Verge, "Daily Life in Wartime California" in The Way We Really Were, Lotchin ed., 24.

${ }^{171}$ Starr, California, 232. 
of organizing local events and making the lonely feel at home."172 There were nearly three thousand USO clubs nationwide. They required an army of civilian volunteers in order to function. Women who volunteered in USO clubs served in a variety of roles. They became dancing partners, talked with soldiers, played cards, and organized and played in ping-pong tournaments. Volunteers with the USO helped the wounded compose letters as well. They also handed out books to soldiers at military bases. ${ }^{173}$

In San Francisco, soldiers could visit the Hospitality House at the Civic Center. There they could play a game of pool or ping-pong as well as converse with young ladies from the various organizations that composed the USO. Near the end of the war, this USO center held a dance for ten thousand invited soldiers; it was the largest USO dance of the war. ${ }^{174}$ Such events required an incredible number of volunteers. Not only did the USO need to round up ten thousand young ladies to volunteer to dance with the soldiers but they also required hundreds if not thousands of chaperones and other support staff in order to successfully hold an event of such enormous proportions. The USO was not picky about its volunteers as evidenced by a humorous quotation from the 1942 book Calling All Women, "The U.S.O. needs women workers. It can use you if you are young and pretty, if you are young and not pretty, if you are middle-aged, if you are old and gray. All it asks is co-operation—willingness to do what you are asked to do."175

The USO became such an immense organization that other volunteer organizations were founded specifically with the intention of aiding its expansion into the

${ }^{172}$ Weatherford, American Women and World War II, 231.

${ }^{173}$ Yellin, Our Mothers War, 169.

${ }^{174}$ Starr, California, 231.

${ }^{175}$ Yellin, Our Mothers; War, 170.

Yellin describes the book Calling all Women as a sort of guide to "volunteer opportunities for women in wartime." 
smaller communities of California. In Santa Maria, citizens formed the "Citizens'

Committee of the USO." The Chairman of the organization, J. Ben Wiley, explained that its object was "to assist in taking the service of the U.S.O. to soldiers and their families in every possible manner." The Santa Maria Daily Times reported on the activities and duties of the Citizen's Committee of the USO. These duties were:

Survey the city for rooms for possible use by the wives or other relatives of soldiers coming here; to ascertain and make available to soldiers facts on the coast and the quality of accommodations in the local hotels and eating places; to assist in securing articles needed in the camp for day rooms, libraries, etc.; to furnish chaperones for dances and hostess committees for the various events in the local center. ${ }^{176}$

The mere existence of groups such as the Citizens Committee of the USO demonstrates Californian desire to support anything that aided the troops.

The USO catered to more than just the men in the armed forces and their families. In Richmond, California, the USO offered special programs for African Americans who labored in the war industries. It also made a failed attempt at building a recreation center for black war workers in Richmond. The area selected was Point Richmond, a white working-class neighborhood. Angered white citizens circulated a petition and eventually convinced the city council of Richmond to prevent the USO from building the center. ${ }^{177}$

The celebrities and ordinary citizens that volunteered with the USO played an integral role in the war effort. USO centers throughout California provided soldiers on their final leave with a positive place to go. California's cities were full of temptation and dangers for the mass influx of soldiers, gambling, rowdy bars, and prostitution abounded. In addition, violence in the form of fights and assaults often occurred. Local leaders scrambled to recruit larger police forces from an ever shrinking pool of men. The USO

\footnotetext{
176 “Group Formed to Serve U.S.O.," Santa Maria Daily Times, 14 April 1942, pg. 1.

${ }^{177}$ Johnson, The Second Gold Rush, 129.
} 
centers in California's cities provided a safe and comforting place for soldiers to spend their leave. Those that volunteered there strove to provide comfort to soldiers. Most of these soldiers were already far away from home, and many, unfortunately, never saw home again.

USO centers and other USO home front activities in California proved to be vital to the war effort from a civilian perspective. They provided an outlet for those who wanted to do anything they could to aid the war effort. Unlike some, more undesirable, volunteer activities such as collecting scrap and other forms of waste, volunteering with the USO was one way in which young women in particular could enthusiastically take part. $^{178}$

${ }^{178}$ Unfortunately some of the young women who wanted to volunteer for the war effort became a bit too "enthusiastic" and became known as "Victory Girls." Yellin points out that these girls, usually between the ages of fourteen and twenty, because of what is assumed to be misplaced patriotism "hung around military bases and had sex with men "for free"...they would not have sex with civilians, only military men." Of course these women only made up a miniscule percentage of women during the war and were vastly outnumbered by those who volunteered in much more noble ways. See: Yellin, Our Mothers' War, 316. 


\title{
VOLUNTEERISM IN A HETEROGENEOUS CULTURE: RACE AND VOLUNTEERISM IN CALIFORNIA
}

\author{
Ill-treatment of minorities always makes for bad morale; \\ so does prejudice and hypocrisy; and so does faithlessness to a trust \\ $\sim$ Arthur Upham Pope, 1942 ${ }^{179}$
}

In California and the rest of the United States, World War II drew out and intensified various racial issues. While communities such as Richmond discriminated against minority groups and tried to prevent them from becoming a part of mainstream society, some white volunteer groups attempted to unite all races in America in the effort to win the war. Minority groups used volunteerism to prove their equality and fight to show that they too could aid the war effort. Across California racial strife clashed with efforts to include everyone. Yet what emerged during and after the war predicted the course of civil rights in America for the rest of the twentieth century. African Americans, Mexican Americans and even interned Japanese Americans contributed to volunteer efforts on the home front despite the fact not as much evidence supporting their contributions. ${ }^{180}$

Though minority groups faced discrimination and hate they also found unlikely supporters. White churches and the AWVS played an important role in promoting racial unity and advancing the cause of minority volunteerism. Through the actions of minority groups and their white supporters, World War II became a watershed moment in American race relations. As historian Ronald Takaki concludes; "Although the war was

\footnotetext{
${ }^{179}$ Pope, "Healthy Morale In Wartime," in America Organizes to Win the War, 261.

${ }^{180}$ One of the reasons that little primary source evidence exists regarding minority participation in mass voluntary efforts is that minority groups were often forced to volunteer among their own ethnic groups. White run newspapers preferred to report on white volunteer groups. In larger national efforts such as scrap drives and victory gardens, newspapers preferred to report numbers rather than the races of those volunteering. Unfortunately most works focusing on minority groups in California during World War II focus on each group's struggle against racism and segregation virtually ignoring more benign home front activities.
} 
not altogether "good," to borrow Studs Terkel's term, the fierce fight against fascism

helped to teach Americans of an ethnically diverse society how to accept one another and

live together as one people."181

African Americans found themselves fighting fascism overseas and for equality

on the home front. The mobilization and population shifts of World War II disrupted

traditional African American culture and society as many moved to California in search

of war work. ${ }^{182}$ In the industry heavy San Francisco bay area, the African American

population swelled as ever more people arrived in search of work at the ship yards that

were the life blood of the war effort in the Pacific. ${ }^{183}$ Much of the African American

experience on the home front in World War II revolved around the cultural stress caused

by mobility and the fight for equality. The Double Victory concept was essential to the

African American war effort. An idea first popularized in a letter from James G.

Thompson, a cafeteria worker at the Kansas Cessna aircraft plant, to the Pittsburgh

Courier, the Double V became the battle cry for African Americans and other

${ }^{181}$ Ronald Takaki, Double Victory: A Multicultural History of America in World War II (Boston: Little, Brown and Company, 2000), 233.

${ }^{182}$ Shirley Ann Wilson Moore credits the mobility of World War II with encouraging "the evolution of African Americans from a largely rural, agrarian population to an urban, industrial one. The war not only dispersed African Americans throughout the United States, but it also disseminated African American culture in the larger society." See: Shirley Ann Wilson Moore, "Traditions from Home: African Americans in Wartime Richmond, California" in Erenberg and Hirsch, eds., The War in American Culture, 269.

${ }^{183}$ In San Francisco, the African American population in 1940 was under 5,000 by 1945 it was 32,000. In Oakland the African American population was 8,000 in 1940 and grew to almost 22,000 by 1945. In Richmond the black population reached 5,000 in 1945 up from 270 in 1940. Unfortunately this growth may have had side effects. According to Kevin Allen Leonard; "In larger African-American communities, it may have been easier for people to isolate themselves from outsiders. A similar process may have occurred in Southern California...In general, the war increased the percentages of African Americans or Mexican Americans in previously mixed neighborhoods." Leonard also points out that the city of Los Angeles in 1940 had a population of around 64,000 African Americans with approximately another 11,000 living in the surrounding areas outside of the city limits.

See: Kevin Allen Leonard, "'Brothers under the Skin"? African Americans, Mexican Americans and World War II in California” in Lotchin, ed. The Way We Really Were, 189, 192-193. 
minorities. ${ }^{184}$ Attaining the Double V became the main goal of African American volunteers.

Unfortunately the trend among most historians that specialize in African

American history has been to stress the second part of the Double V concept, victory over enemies on the home front, and virtually ignore African American support for the war effort. In California, as evidenced by their participation in voluntary activities, African Americans supported the war effort in ways similar to white Americans. ${ }^{185}$ The Women's Army for National Defense (WAND) was an exclusively African American group that operated chapters nationwide. WAND's mission statement; "an instrument through which our women could serve in this great crisis, with dignity and pride" makes it clear that victory abroad was every bit as important as winning equality at home. ${ }^{186}$ Much like any of the other volunteer organizations founded during World War II, WAND sold war bonds and participated in civilian defense programs. It also provided day care centers for the children of African American women working in the war industries. ${ }^{187}$ African American women also joined AWVS which was one of the few privately run white

${ }^{184}$ Thompson outlines the concept of the Double V in his letter; "The V for victory sign is being displayed prominently in all so-called democratic countries which are fighting for victory over aggression, slavery, and tyranny. If this $\mathrm{V}$ sign means that to those now engaged in the great conflict, then let we colored Americans adopt the double VV for a double victory. The first $\mathrm{V}$ for victory over our enemies from without, the second $\mathrm{V}$ for victory over our enemies from within. For surely those who perpetrate these ugly prejudices here are seeking to destroy our democratic form of government just as surely as the Axis forces."

See: Takaki, Double Victory, 20.

${ }^{185}$ Roger Lotchin laments; "By concentrating only on the bias part of the V, historians have made it seem that African Americans were indifferent to the most important event of the twentieth century. Specialists in black history have not told the story of African American's support for the war effort, so the generalist cannot create a larger story for which the specialists have not provided the pieces."

See: Lotchin, The Bad City in the Good War, 133.

${ }^{186}$ Yellin, Our Mother's War, 209.

${ }^{187}$ Yellin, Our Mother's War, 209. 
organizations that accepted African American and other minority women into its ranks. It prided itself on reaching out to all women no matter their background or race. ${ }^{188}$

The USO and the Red Cross in particular served as a voluntary outlet for African American volunteers on the home front in California although these organizations were segregated. Throughout the war, the USO had separate clubs for White and African American soldiers. Though these facilities furthered the "Jim Crow" policies of much of America, they provided advocates of the Double $\mathrm{V}$ with a reminder of what they were fighting to end. The Red Cross also accepted African American volunteers, although on a very limited scale. Initially the Red Cross did not allow African Americans to donate blood, but later in the war African American blood donation was permitted and even encouraged. Following the norms of the "Jim Crow" era, African American blood was kept segregated from white donated blood and was only used in aiding African American servicemen. ${ }^{189}$ African American volunteers from all backgrounds faced discrimination as they carried out volunteer work, but yet they still volunteered. Those that volunteered showed a strong desire to help the United States win the war. African American volunteers well understood the concept of the Double V, and understood that by just participating in the war effort they could make societal gains.

Not all African American volunteers were forced to live with the segregation imposed upon them by the war effort. A few exceptional individuals controlled their own destiny, volunteering in their own way on their own terms. The African American women who volunteered with the AWVS were one such group and Hollywood performer, singer, and actress Lena Horne became an exception to the segregation rule, though this was of

\footnotetext{
${ }^{188}$ Yellin, Our Mother's War, 209-210.

189 Sittser, A Cautious Patriotism, 179.
} 
her own accord. Horne was easily the most popular African American entertainer and actress in the early years of the war. She was one of the first African American actresses to sign a long term contract with a major Hollywood movie studio. ${ }^{190}$ Horne became increasingly popular as a USO performer who toured the United States singing and performing at military bases. Throughout the course of her USO tours, she began to be frustrated by the segregation that she witnessed in "Jim Crow" America. As she states in her autobiography:

I always expected to entertain the white soldiers first, then the Negroes...I was getting full —up to here-with the whole situation, but I wasn't about to quit USO work, for I was genuinely lovingly received by the men of both races and I wanted to be with them. At least when we appeared we gave the guys a little recreation, a little respite from the Army and, for the Negro soldiers, a respite from the special hell to which they were assigned. ${ }^{191}$

Eventually Horne tired of this system. Her patience reached a breaking point one day when her troupe was forced to perform two separate shows at a military base. She had gotten used to performing in a crowded hall in which white soldiers were seated in the front while African American soldiers were relegated to the rear, but this show infuriated her. The night show, in which her troupe performed, was exclusively for the white soldiers on the military base. The next morning, at the show intended to be for African American soldiers, a large group of German prisoners of war were seated at the front of

${ }^{190}$ Yellin, Our Mother's War, 218. Horne's contract, signed in 1942, even stipulated that she would not act in roles that required her to be a maid or jungle native, the only roles typically open to African American women in the time. Yellin says; "As a result Horne often was relegated to being a singer only, without any speaking part, so that her segments could be cut out of the versions shown in southern movie theaters. Audiences in Jim Crow states apparently could not tolerate seeing black people on the screen with white people except as servants or in other second-class guises."

${ }^{191}$ Lena Horne and Richard Schickel, Lena (New York: Signet Books, 1965), 131-132.

Cited in: Yellin, Our Mother's War, 218-219. 
the auditorium, and the African American soldiers were forced to sit behind them. ${ }^{192}$

Horne had seen enough and was tired of being forced to perform under such conditions.

She quit the USO tour and began her own tour of military camps at her own expense but

performing on her own terms. ${ }^{193}$ Horne was fortunate in the fact that she had the financial means and the celebrity draw to break out of the "Jim Crow" dominated power structure and volunteer in her own way.

All around California African Americans volunteered much in the same way that white Californians did. Most faced the disadvantage of being outsiders who had migrated from other states in order to find work. Yet they still volunteered. They worked at USO clubs and joined the volunteer organizations that accepted them such as the AWVS. In areas where no such organizations existed they formed their own such as WAND. Clearly African Americans supported the war effort to attain a double victory. They were not ambivalent about the war itself though. African American voluntary efforts demonstrate that not only were African Americans focused on attaining a victory for equality at home but also earnestly fighting to help America defeat its enemies abroad.

Mexican Americans in California faced similar struggles to those of African Americans. They too desperately wanted America to win the war. They also fought for the Double V. There had been Mexican American families in California for generations, but even those who immigrated under the Bracero program felt a strong connection to

${ }^{192}$ Giving German POWs preferential treatment over African American Soldiers in the American South was not relegated to just this solitary incident. Martha Settle, who served with the Women's Auxiliary Corps (WAC) remembered; "the anger she felt when a group of German officers, who were POWs at a garrison in the Des Moins area, were invited into the Fort Des Moines officers' club while the black officers were barred." See: Brokaw, The Greatest Generation, 187.

193 Yellin, Our Mother's War, 220. 
California and a need to aid in the war effort. A song sung by the braceros elaborates on

this dedication;

If this war carries on

We're all damned!

We'll have to punch

Hirohito out...

We'll have to give our help

To the United States,

If we do that, no doubt

We'll never be beaten. ${ }^{194}$

Though not volunteers themselves, the braceros and their songs demonstrate a sense of

patriotism among a group whose role on the home front in California is often relegated to

discussions of the Zoot Suit Riots and other instances of racial strife. ${ }^{195}$

Mexican American labor and civil rights group El Congreso was enthusiastic in

its hatred of the fascism that had overtaken Europe and Asia. It prodded Mexican

Americans to join in the fight. El Congreso urged unity between Mexican Americans and

other Americans and argued that the battle against fascism was "the most profound civil

194 Takaki, Double Victory, 93.

The Bracero program began in 1942. Under the program, the United States recruited guest laborers in Mexico who worked in California and twenty-one other states under contract and were to be returned to Mexico when their contract expired. The program continued long after the war. From the beginning of the program to 1947200,000 braceros had worked in the United States. In 1944 alone, braceros harvested $\$ 432$ million worth of crops.

See: Takaki, Double Victory, 92-93.

${ }^{195}$ The Zoot Suit Riots were a result of years of racial strife resulting in general mistrust between Mexican Americans and White Americans living in the Los Angeles area. Former state Librarian of California and Historian Kevin Starr describes the riots, "All these forces came together on June 3, 1943, when two sailors made moves on two Mexican American girls at a dance in the seaside Venice district of Los Angeles and provoked a full scale brawl between sailors and Mexican American youths, some of them in zoot suits. That same evening, eleven sailors got into a fight with a group of Mexican American young men in the down town... On the evening of Friday, June 4, a caravan of twenty-nine taxicabs took some two hundred sailors and marines through the city. Upon sighting a zoot-suiter the sailors and marines would stop the caravan, pour out into the street, and surround the hapless victim...they would proceed to rough up their captive...The rioting continued through the weekend, fanned by screaming headlines and sensational press reports that five hundred zoot-suiters were organizing a counterattack."

See: Starr, California, 233-234. 
rights issue of the day." ${ }^{196}$ Before the war, El Congreso fought for civil rights gains, but during the war it refocused on unity. Voluntary efforts were but one way in which Mexican Americans could promote unity within their own ethnic group and within society as a whole. Historian George Sánchez argued that the activities of political and labor groups such as El Congreso were the greatest "Americanizing agent" among Mexican Americans in the 1940s. ${ }^{197}$

Mexican Americans made up a significant part of urban California, particularly Southern California. A conservative estimate places the number of people with Mexican ancestry living in the Los Angeles area in 1940 at 219,000. Of this number roughly 65,000 were defined as Mexican Americans. ${ }^{198}$ The total population of Los Angeles County was 2,785,643. ${ }^{199}$ Roughly ten percent of the population was of Mexican ancestry. The population mobility of World War II brought de-barrio-ization to California's Mexican Americans. It also brought upward mobility, although gains came slowly and with much difficulty. ${ }^{200}$ The Mexican American population of California supported the concept of the Double V, and much like African Americans, their goal at home was integration into the American mainstream. According to Roger Lotchin, Mexican American's made modest gains in terms of racial equality and acceptance into

${ }^{196}$ George J. Sánchez, Becoming Mexican American: Ethnicity, Culture and Identity in Chicano Los Angeles, 1900-1945 (New York: Oxford University Press, 1993), 248.

${ }^{197}$ Sánchez, Becoming Mexican American, 249.

${ }^{198}$ Leonard, "African Americans and Mexican Americans in California," in Lotchin ed., The Way We Really Were, 190.

Leonard says; "Some have argued that the Census Bureau seriously undercounted the number of Mexican Americans in Southern California."

199 Richard L. Forstal, ed, "Population of Counties by Decennial Census: 1900 to 1990” in U.S. Census Bureau [cited 10 October 2008]; available from: http://www.census.gov/population/cencounts/cal190090.txt

${ }^{200}$ Starr, Embattled Dreams, viii. 
society. ${ }^{201}$ For Mexican American women in particular war work, volunteer and otherwise, provided for new levels of independence and self reliance

. Mexican Americans volunteered out of patriotism and experienced personal growth in the process. Even those who were of the first generation of their family born in the United States saw themselves as Americans, as one woman commented, "My generation went proudly to war because this country, despite the discrimination, had provided my family with a better life than my relatives had in Mexico."202 Despite early war allegations of pro-Axis elements among the Mexican population of Southern California, Mexican Americans were fiercely patriotic and did their best to aid the war effort on the home front. Those who volunteered did so with all of the same gusto as other racial groups in California. ${ }^{203}$

${ }^{201}$ Lotchin, The Bad City in the Good War, 118-119.

202 Takaki, Double Victory, 101.

${ }^{203}$ El Congreso was accused of being a part of the Communist party's "Popular Front strategy." During the war, it defended the Mexican Americans accused of murder in the Sleepy Lagoon case. Members also fought for the rights of Mexican American laborers by serving on the Fair Employment Practices Commission. Actions such as these led to accusations of being "un-American" and "communist" as early as 1943. It seems that Mexican Americans, being the hated other, could not escape ties to movements that frightened mainstream Americans be they fascist or communist.

See: Sánchez, Becoming Mexican American, 246, 249. 


\section{POTENTIAL FIFTH COLUMN: JAPANESE AMERICAN VOLUNTEERISM BEFORE AND DURING INTERNMENT}

One of the only minority groups that did not benefit from increased equality and acceptance during World War II was Japanese Americans, despite the fact that many Japanese Americans were as fiercely patriotic as other groups of Americans. ${ }^{204}$ Racial hatred and the fact that the United States was at war with Japan led to Japanese Americans being rounded up and sent to relocation camps for much of the war. Before they were interned, Japanese Americans tried in vain to prove their patriotism through volunteer work. In the days after the attack on Pearl Harbor, the Japanese members of many communities in California openly condemned the attacks. The San Diego Union published a letter from the Japanese American Citizens League condemning Japan and calling the attacks an "unprecedented breach of good faith." A Japanese group in Chula Vista called the attack one of "treacherous infamy" and said "We do not hesitate to repudiate and condemn our ancestral country when Japan deliberately attacks us and American blood was shed."205

Though the Japanese community was trying to prevent backlash against itself, many of its members were also fiercely patriotic and earnestly wished to aid the war effort. Prior to internment many Japanese Americans used volunteer work to show their loyalty to the United States and to aid the war effort, "mothers volunteered their sons for

${ }^{204}$ At least one young Japanese-American was a little too patriotic for his family's tastes. The Santa Maria Daily Times reported on February 17, 1942 that sixteen year old Hiroshi Shiba was beaten by his father and two brothers for telling them that he wanted to become and aviator in the United States Army Air Corps. He fled to the police after receiving a beating and reported that his parents were "violently antiAmerican and harbored guns in their residence." The police were amazed that the youth's "courage and devotion to the United States" was greater than "the strong family ties that are characteristic of the Japanese.” See: “Jap Dad Beats Patriotic Son,” Santa Maria Daily Times, 17 February 1942, pg. 1.

${ }^{205}$ Lotchin, The Bad City in the Good War, 105-106. 
military service; picture brides rolled bandages; and fishermen willingly gave up their livelihoods to reassure the Navy about maritime espionage and offered their boat radios, critical skills, and other equipment to the Navy.",206

Initially Governor Culbert Olson of California praised the effort and participation of Japanese Americans in voluntarily aiding the war effort. Unfortunately, by the end of December 1941 an overtly anti-Japanese tone had infiltrated most California newspapers turning public opinion against Japanese Americans. ${ }^{207}$ After Executive Order 9066 was signed and carried out, volunteer opportunities for Japanese Americans became nearly non-existent as they were instead forced to focus on surviving in the poor living conditions of the internment camps. Their lives were made all the more difficult by the harsh climates of the locations. Some opportunities to aid the war effort did exist in the internment camps. Internees were paid nineteen dollars a month to weave camouflage netting, and though they were getting paid a pittance for this work, Japanese Americans used this type of work as a sort of volunteerism to aid the war effort, as they weren't forced to participate. ${ }^{208}$

Surprisingly, some atypical White run volunteer organizations supported the interned Japanese and attempted to make certain that they were treated humanely. These organizations tried to explain their support of interned Japanese Americans and argued that Japanese Americans represented an entire segment of the population that was willing and able to aid America in its war effort rather than sit in camps separated from the rest

${ }^{206}$ Lotchin, The Bad City in the Good War, 106.

${ }^{207}$ Lotchin, The Bad City in the Good War, 106.

The first California newspaper to call for Japanese American exclusion and expulsion was the Independent of San Luis Obispo. This was only five days after Pearl Harbor!

${ }^{208}$ Ronald H. Bailey, The Home Front U.S.A., vol. 8 of World War II (Alexandria, VA: Time-Life Books, 1977), 36. 
of society. Groups such as the American Civil Liberties Union (ACLU) and the

Fellowship of Reconciliation led the fight along with a multitude of smaller church groups. ${ }^{209}$ Even though these groups vehemently opposed internment they did concede that at the beginning of the war internment was probably a military necessity.

The religious press kept its readers informed of living conditions and religious atmosphere in the internment camps. It also advocated more inclusive immigration and naturalization laws. Churches and individuals also volunteered their time to minister to Japanese Americans in camps throughout the duration of the war. ${ }^{210}$ No American church group was more critical of the internment than the Methodist Church. At a conference in 1942 the church accused "powerful interests, popular war hysteria, provincialism, and vigilantism of precipitating the crisis... The guilty party was not the Japanese at all but the American people, particularly reporters and “pseudo-patriotic bullies.",211

The internment of Japanese Americans in World War II was one of the terrible consequences of the extreme patriotism that swept throughout the United States and California in the wake of the Pearl Harbor attacks. The Native Sons of the Golden West (NSGW), a volunteer organization founded in 1875, and its sister group the Native Daughters of the Golden West worked especially hard to promote discrimination against Japanese Americans. $^{212}$ The American Legion along with various labor groups, and local

${ }^{209}$ Blum, $V$ was for Victory, 162.

${ }^{210}$ Sittser, A Cautious Patriotism, 175.

${ }^{211}$ Sittser, a Cautious Patriotism, 174.

Blum also mentions Vigilantism as a factor that necessitated internment. He quotes a contributor to The Nation writing in February 1942, "for the sake of war efficiency,' surveillance by the FBI would 'suppress the ancient Western curse of vigilante rule."

See: Blum, $V$ was for Victory, 162.

${ }^{212}$ Blum, $V$ Was for Victory, 158.

The NSGW was founded to promote the history and mythology of the early days of California. It is characterized as a charitable fraternal organization. Although throughout its history it has been rather nativist and supported discrimination against Asian Americans, it has expelled such elements from its 
governments demanded the removal of Japanese Americans from the West Coast. ${ }^{213}$ Still jittery from the Pearl Harbor attacks, Californians' fears of invasion increased on Febuary 23, 1942 when Japanese submarine I-17 fired twenty-five five-inch shells into the storage tanks of the Bankline and Barnsdall oil companies only twelve miles north of Santa Barbara. ${ }^{214}$ Citizens who witnessed the submarine surfacing offshore reported what they saw to local authorities. Reverend Arthur Basham said that he saw the sub using signal lights to communicate with an unknown person on shore. ${ }^{215}$ News such as this amplified anxiety and led to increasingly vicious actions against Japanese Americans. As average Californians actively attacked Japanese Americans in a show of their own patriotism businesses began to take notice. An advertisement from a mortuary read: "I'd rather do business with a Jap than with an American" and one California barber promised "free shaves for Japs" but warned that he was "not responsible for accidents." 216 AntiJapanese fervor among Californians exploded into demands for relocation. Volunteer organizations such as the NSGW and the American Legion along with individual citizens worked diligently to strip Japanese Americans of their rights, land, and businesses as a means of civil defense. It was one of the negative aspects of unbridled volunteerism.

Though eventually Japanese Americans gained civil rights, they did not experience the step into society that African Americans, Mexican Americans, and other minority groups experienced. World War II was described by Roger Lotchin as a

organization and instead focuses on preservation of historical sites, and charitable actions such as helping children afflicted with "Craniofacial anomalies" See: Native Sons of the Golden West [cited 9 February 2009]: available from http://www.nsgw.org/index.htm .

${ }^{213}$ Blum, $V$ Was For Victory, 158.

Blum points out that most of these groups were motivated by financial gains that they would get by seizing Japanese American property and goods.

${ }^{214}$ Starr, Embattled Dreams, 63.

${ }^{215}$ Starr, Embattled Dreams, 63.

${ }^{216}$ Blum, $V$ Was for Victory, 158. 
"watershed" for California. ${ }^{217}$ It was a "watershed event" for both African Americans and Mexican Americans in the sense that through volunteerism and steeping into new employment opportunities opened to them during the war, the issue of race relations was forced into public discourse for the first time in the twentieth century. For Japanese Americans too World War II served as a "watershed" moment. While interned in camps their loyalty and love of America was tested by a nation that saw them as nothing more than a potential fifth column.

${ }^{217}$ Lotchin, The Bad City in the Good War, 104. 


\section{THE “GOOD” ASIAN IN THE “GOOD” WAR: CHINESE AMERICAN VOLUNTEERISM IN WORLD WAR II CALIFORNIA}

The one group that, ironically, benefited because of the anger and hatred directed towards Japanese and Japanese Americans was Chinese Americans. World War II led to the most dramatic change in Chinese American social roles in nearly a century. ${ }^{218}$ By the end of the war, they occupied a new status in society largely because they played the role of the "good Asian" in the "good war.",219 Chinese Americans actually attained towards their Double V during the war. It allowed them to finally become a part of the country that they loved. ${ }^{220}$ Charlie Leong of the San Francisco Chinatown understood the importance of World War II in altering the Chinese American role and identity. He called the war "the most important historic event of our times" and argued that "for the first time we felt we could make it in American society." ${ }^{, 221}$ Chinese Americans in California volunteered during the war to show their dedication to America and in turn earned greater acceptance in American society.

Before the United States entered the war, Chinese Americans in California used volunteerism to support the Chinese cause against Japan. Since the Japanese invasion of Manchuria in 1931, Chinese Americans had done their best to aid the war effort in their

${ }^{218}$ Wong, Americans First, 72-73.

${ }^{219}$ Wong, Americans First, 124.

See Also: K. Scott Wong, "War Comes to Chinatown: Social Transformation and the Chinese of California" in Lotchin ed., The Way We Really Were, 165.

See Also: Lotchin, The Bad City in the Good War, 118.

${ }^{220}$ Perhaps most importantly, in 1943 the long standing Chinese Exclusion Acts were repealed and Chinese could finally immigrate to America and Chinese immigrants could apply for American citizenship. See: Wong, "War Comes to Chinatown" in Lotchin ed., The Way We Really Were, 181.

${ }^{221}$ Takaki, Double Victory, 116.

Chinese volunteerism did not just encompass home front activities. Much like other minority groups, Chinese Americans also volunteered to serve in the armed forces. 13,499 Chinese Americans served total, this constituted 22 percent of all Chinese American adult males.

See: Takaki, Double Victory, 115-116. 
ancestral lands. Initially, Chinese American groups boycotted Japanese goods and started a movement to stop America from shipping scrap iron to Japan. ${ }^{222}$ These displays of solidarity helped to heighten the awareness of the plight of China at the hands of Japan. The primary Chinese American volunteer organization prior to America's entry into the war was the Chinese War Relief Association (CWRA).

Rice bowl parties were a popular and successful volunteer fundraising effort practiced by the CWRA and other Chinese American groups. These parties featured Chinese and western music, dancing, parades, street theater, and fashion shows. One rice bowl party held in San Francisco's Chinatown in 1938 hosted nearly two hundred thousand people and raised fifty-five thousand dollars. All of this was accomplished in a single day. Rice bowl parties held by the same Chinatown in 1940 and 1941 each doubled the attendance and funds raised at the 1938 party. ${ }^{223}$ These efforts semt more than just money to China. In 1940 the Chinese News reported, "Early contributions made by overseas Chinese to China have been in the form of direct relief funds; the purchase of Liberty Bonds; the sending of winter clothing, ambulances, and medical supplies; and support for the 'Warphan' and 'Friends of the Wounded' campaigns., 224

Once America entered the war the volunteer efforts already in place in the Chinese American community, were refocused toward aiding the American war effort. San Francisco's Chinese Press made the intentions of Chinese Americans perfectly clear in its patriotic editorial "A Memo to Mr. Hitler, Hirohito \& Co.":

...San Francisco Chinatown, U.S.A., is joining the party. Chinatown will have fun blasting you to hell. Chinatown is proud to be a part of Freedom's legion in

${ }^{222}$ Wong, Americans First, 74.

See also: Lotchin, The Bad City in the Good War, 115.

${ }^{223}$ Lotchin, The Bad City in the Good War, 115.

${ }^{224}$ Wong, "War Comes to China Town" in Lotchin ed., The Way We Really Were, 178. 
freeing all the decent people of the world from your spectacle. Chinatown's part of the party will cost $\$ 500,000$. Admission price to the fun is purchase of a U.S. War Bond. We're all going to buy a War Bond for Victory. P.S. More bad news. Everyone in Chinatown is going to this party. We're NOT missing this one. ${ }^{225}$

Chinese Americans volunteered with gusto throughout the war. Not only were they fighting to save their homeland but their ancestral land as well. Chinese American operated newspapers, emboldened by Chinese Americans' new found acceptance in American society, called for total participation in the war effort. The Chinese News reflected this newfound patriotism and wrote; "The duty of every Chinese in America is to participate in the defense of this country.",226

Chinese Americans took the call to action from papers such as Chinese News and Chinese Press very seriously and volunteered in droves. The Independent Woman, a monthly magazine of the era, printed an article titled "Chinese Daughters of Uncle Sam," in which it highlighted Chinese women's efforts in war labor and volunteerism "American girls of Chinese ancestry are devoting their hands and their minds to an all-out victory effort. In aircraft plants, training camps, and hospital wards, at filter boards and bond booths, in shipyards, canteens, and Red Cross classes, these girls are doing their utmost to...hasten the end of the war."227 In 1944 the Chinese Young Women's Society (CYWS) was founded by Dorothy Eng of Oakland, California. This group provided clubs similar to USO clubs and catered exclusively to Chinese American soldiers. The CYWS founded these clubs as a response to fears that Chinese American soldiers may not be welcome at regular USO clubs since most other minority groups were not. ${ }^{228}$ Chinese

\footnotetext{
${ }^{225}$ Takaki, Double Victory, 115.

${ }^{226}$ Wong, Americans First, 81.

${ }^{227}$ Wong, Americans First, 47.

${ }^{228}$ Wong, "War Comes to Chinatown," in Lotchin ed., The Way We Really Were, 179.
} 
American Women also benefited from unprecedented gains in racial acceptance. Unlike African American women, and those of other minorities, neither the Red Cross, nor the USO, nor the YMCA discriminated against them. ${ }^{229}$

In San Francisco, Chinese Americans along with other nationality groups participated in the national "I Am an American Day" festival. The festival was an invention of the Department of the Treasury's War Savings staff. Each group that participated ran a booth selling handmade goods representative of their country of origin. The money earned was used in the war effort. ${ }^{230}$ "I Am an American" became the unofficial mantra of the Chinese American community. ${ }^{231}$

Around California, Chinese Americans wrote to newspapers describing their voluntary efforts and patriotism. They extolled others to contribute all that they could to the war effort. They saw themselves as Americans first and Chinese second. For the "I Am an American" Contest put on by the Oakland Post-Enquirer, fifteen-year-old Florence Gee wrote, "I am a American-born Chinese. Like all American girls, I have a heroine...My sisters are members of the civilian defense. My mother is taking first aid...I help my church collect money for the United China war relief. That which helps China

\footnotetext{
Wong quotes Dorothy Eng's reasoning for utilizing the CYWS to found such clubs; "We were still being discriminated against even though the law [exclusion acts] had already been rescinded. It hadn't filtered down to ordinary people. Our service boys were not-well, we can't say that they weren't well received. Maybe they wouldn't be well received, but they were not going to chance it. You are not going to walk into the USO and be snubbed or ignored. Why chance it? So unless we provided a center in each community for Chinese boys, they had no place to go, no common place to meet."

${ }^{229}$ Lotchin, The Bad City in the Good War, 115.

${ }^{230}$ Wong, "War Comes to Chinatown," in Lotchin ed., The Way We Really Were, 180. See Also: Gary R. Mormino and George E. Pozzetta, "Ethnics at War: Italian Americans in California during World War II," in Lotchin ed., The Way We Really Were, 151-152.

Mormino and Pozzetta's piece also discusses "I Am An American Day" and its vital role in showing mainstream Americans that minority groups in America (in this case Italian Americans) had Americanized.

${ }^{231}$ The phrase "I am an American" was adopted by many immigrant groups in California during the war. It became a form of socialization into the mainstream of American society.
} 
helps America." ${ }^{232}$ For a different contest, twelve-year-old Eleanor Yee wrote, "God had given me my birthplace in an unconquerable United States of America...We are all Americans, whatever our race, color, or creed...Every loyal American should contribute gladly and freely in whatever way he can to help win the war." ${ }^{, 233}$ Her essay won the "I Am an American" essay contest held by the Chinese American Citizens Alliance.

The Second World War provided both revolutionary and evolutionary opportunities for Chinese Americans in American society. Though change progressed slowly Chinese Americans gained unprecedented levels of acceptance during and after the war. ${ }^{234}$ Chinese American volunteerism demonstrated to mainstream American society that Chinese Americans truly were Americans. As Kevin Scott Wong said:

no longer relegated by race and ethnicity to low-paying jobs, the social transformation brought on by World War II marked the opportunity for Chinese Americans to advance into the American middle class...Through the hindsight of historical inquiry, it is now evident that the war left Chinese Americans at the threshold of social mobility and increased assimilation. ${ }^{235}$

Chinese Americans' eagerness towards volunteerism attracted the attention of mainstream Americans, and facilitated the rise in status described by Wong. This is in stark contrast to Doris Weatherford's claims that volunteerism was simply a 'bandage' that made the United States' problems worse. The volunteerism of Chinese Americans in California was not simply "part-time" as Weatherford describes it but rather it was fundamental to the war effort even if just for the sake of improving the morale of Chinese Americans and mainstream Americans alike. ${ }^{236}$

\footnotetext{
${ }^{232}$ Wong, Americans First, 70-71.

${ }^{233}$ Wong, Americans First, 71.

${ }^{234}$ Wong, "War Comes to Chinatown," in Lotchin ed., The Way We Really Were, 182-183.

${ }^{235}$ Wong, "War Comes to Chinatown," in Lotchin ed., The Way We Really Were, 183.

${ }^{236}$ For Weatherford See: Weatherford, American Women in World War II, 236.
} 


\section{AFTER V-DAY: \\ WORLD WAR II, CALIFORNIA AND CHANGE}

World War II brought drastic change to the state of California. Not all of this change was immediate; much of it played out over the course of the following decades. The communities strengthened by volunteerism played a vital role in easing California's transformation from a West Coast outpost to the most populated state in the United States. California's experience during the war was different from many other states. New York, already heavily metropolitan, changed little in size and its daily rhythm remained unchanged, for the most part, throughout the duration of the war. Rural areas across the nation experienced the major impacts of the war only indirectly. ${ }^{237}$ The central United States did not live under the constant fear of air raid, and despite intense mobility did not experience the same population growth as California. Over thirty million Americans, a full quarter of the total population, were either drafted or moved for war work during the war. $^{238}$

Many of those who served in the armed forces spent time in California prior to being deployed to the Pacific theatre. Thousands moved to California in search of work in its burgeoning war industry. The vast influx of new people virtually shattered prior community connections and created a new pastiche of people of different races, creeds, and colors in California. California experienced unprecedented economic and population

${ }^{237}$ John W. Jeffries, Wartime America: The World War II Home Front (Chicago: The American Ways Series, 1996), 81.

${ }^{238}$ Lotchin, The Bad City in the Good War, 239.

Lotchin claims that 16 million men were drafted and an additional 15 million people moved in search of war work. 
growth throughout the war. ${ }^{239}$ Women took up roles that prior to the war were unavailable to them and minority groups throughout the state, with the exception of Japanese Americans, experienced new opportunities as well. ${ }^{240}$ Even though, according to Kevin Starr, their path to a new identity as Californians "was filled with repression and hurt," Mexican Americans and African Americans did gain a new identity. ${ }^{241}$ Also, Chinese Americans, for the first time, were able to move into mainstream society.

Volunteerism and the reality of fighting against a common enemy helped to unite disparate groups in California. In organizations such as the AWVS, African American and Mexican American women served alongside white women. The volunteer organizations that excluded minority groups, or practiced segregation served as a rallying point for minority volunteer organizations such as WAND and CYWS. Minority volunteer groups fought for the Double V by showing exclusionary groups that they too supported the war effort. In non-segregated groups, volunteerism proved to be a uniting factor among people of different races. Although segregation often forced minorities to volunteer within their own group, the spirit of volunteerism during the war created unlikely allies. White churches supported African Americans in their fight for the Double V. The religious press sided with African Americans over discrimination issues and did its best to promote the cause of equality and civil rights for all. ${ }^{242}$ Even the interned Japanese found themselves supported and aided by volunteers from white groups such as the ACLU and the Methodist church. This good will continued after the war as many

${ }^{239}$ The federal government spent \$35 Billion dollars in California between 1940 and 1946. This caused Manufacturing to multiply its economic share by a factor of 2.5. 1.6 Million people moved to California, and the average personal income of Californians tripled between 1939 and 1945.

See: Starr, Embattled Dreams, viii.

${ }^{240}$ See: Lotchin, The Bad City in the Good War, 240. and Starr, Embattled Dreams, viii.

${ }^{241}$ Starr, Embattled Dreams, viii.

${ }^{242}$ Sittser, A Cautious Patriotism, 183. 
church groups continued to minister to Japanese Americans as they returned to their communities. $^{243}$

California in World War II was far from a utopia, but the ever-present fear of invasion and the necessity for unprecedented numbers of volunteers to aid in civil defense created an atmosphere of reluctant racial cooperation and acceptance in the metropolitan areas of California and in the state as a whole. For the most part, "California cities were not marred by incidents like the hate strikes in Mobile or the racial upheaval in Philadelphia." ${ }^{244}$ Though old community ties were often shattered by the vast population mobility of World War II, Volunteerism helped to create new ties. Even though historians, such as John Jeffries, point out that American culture has always been highly mobile. Bond and scrap drives and civil defense efforts were integral in creating new community ties. ${ }^{245}$

${ }^{243}$ Sittser, A Cautious Patriotism, 175.

${ }^{244}$ Lotchin, The Bad City in the Good War, 128.

${ }^{245}$ John W. Jeffries, War Time America: The World War II Home Front (Chicago: Ivan R. Dee, 1996), 86-87. 


\section{DID RUBBER MATS AND VICTORY GARDENS WIN THE WAR?: CONCLUSIONS REGARDING THE CENTRALITY OF VOLUNTEERISM ON THE HOME FRONT IN CALIFORNIA}

Even though invasion and air raids never tested civil defense plans in California and alot of the junk collected in scrap drives was just that, junk, volunteerism played a central role in the war effort on the home front in California. Contrary to Doris Weatherford's claims, volunteerism was not simply a "band aid on a wound that needed surgery."246 Whereas other government run social programs failed to create a sense of community, volunteerism, as promoted by the government and grass-roots organizations, succeeded in creating a sense of community and patriotism that lasted throughout the war. $^{247}$

Arthur Upham Pope's 1942 essay on morale in wartime clearly demonstrates the importance of community and volunteerism in winning wars and keeping morale high "in wartime the individual doesn't count as an individual; he counts only as part of the nation. If he remembers that fact, forgets about himself, and dedicates himself to the good of the nation as a whole, his morale through his very dedication will be as high as morale can well be." ${ }^{248}$ Volunteerism was an example of the individual sacrificing for the greater good of the war effort. Though individual goals became subservient to communal goals

${ }^{246}$ Weatherford, American Women and World War II, 236.

${ }^{247}$ Johnson, The Second Gold Rush, 142.

Johnson argues, "Ultimately, government social programs failed to create a sense of "citizenship" or "community responsibility" among migrant communities in the East Bay area. Volunteerism evident in such communities demonstrates a sense of "citizenship" and "community responsibility" that was a result of the community building nature of volunteer activities.

${ }^{248}$ Pope, "Healthy Morale in Wartime" in America Organizes to Win the War, 264. 
during the war, exemplary individuals were lauded such as, the seven-year old boy who died while aiding a scrap drive. ${ }^{249}$

Volunteerism on the California home front was marked with enthusiasm from the general public and active encouragement and support from federal, state, and local governments. Even though the bombs never fell and the enemy never set foot on Californian soil, civil defense efforts throughout the state created a sense of community and a mutual goal for Californians to work towards. Though the materiel gathered in scrap and paper drives across the state was of sometimes dubious value to the war effort, volunteer efforts created a feeling of community and bolstered patriotism. Volunteers who worked for organizations such as the Red Cross and USO aided the war effort in a more tangible way. They not only provided necessary goods such as first aid packs, blankets, and warm clothes to the troops but also boosted the morale of the troops with volunteerism ranging from entertaining shows to just providing a friendly face to those about to be shipped overseas.

Minority groups struggled to achieve acceptance into mainstream Californian society, and volunteerism was one of many means to demonstrate their patriotism and fight for equality. Though they did not enjoy immediate or dramatic gains, the groundwork was laid for the future of the civil rights movement. Even Japanese Americans, the hated "enemy within," tried their best to prove their patriotism and love of America while interned in what many in the younger generation of Japanese Americans refer to as "concentration camps."

Acts of volunteerism allowed the average Californian to feel intimately involved in the war effort. Nearly everyone knew someone who was actively serving overseas and

${ }^{249}$ For a detailed discussion of this incident see p. 35 above. 
volunteerism allowed them to actively support loved ones who might be thousands of miles away. Likewise, California's experience during the war differed from much of the rest of the United States. Volunteers in California enthusiastically contributed to coastal defense, and, unlike much of the rest of the nation they lived under the very real fear of air raids, especially in the first years of the war. Anti-Japanese behavior, though not unique to California, was intensified by the state's large Japanese American population, and was viewed by most Californians as aiding the war effort. Other groups such as the Methodist Church felt it was detrimental since Japanese Americans could equally aid the war effort. The cultural pastiche that California became during the war created a special set of challenges that had not really occurred until the mass migrations during the war. Cross culturally, Californians volunteered on the home front to help win the war. 


\section{EPILOGUE: \\ MASS VOLUNTEERISM IN CALIFORNIA SINCE WORLD WAR II}

Not since World War II have California and America in general taken part in such a vast military mobilization. Despite this, the spirit of volunteerism continued in California weakening and strengthening as situations demanded. Since World War II, the focus of volunteerism has changed. During the Korean War, the Red Cross provided a variety of services to families of soldiers on the home front. Called the Home Service, it provided:

- "counseling for personal and family problems.

- an emergency link between a distantly stationed man and his family in order to keep the family together and informed during a crisis.

- assistance with applications for government benefits,

- financial assistance,

- referral of family members to other community sources for specialized aid not provided by the Red Cross." 250

Apart from the contributions of organizations such as the Red Cross, there was no deluge of volunteerism on the home front in the Korean War. President Truman's refusal to refer to the war as anything other than a "police action" contributed to apathy among a public weary of warfare..$^{251}$

There was little popular pro-war volunteerism during the Vietnam War. The Red Cross soldiered on by providing recreation programs to soldiers stationed in Vietnam. It sent teams of young female college graduates to the region to "conduct audience-

\footnotetext{
250 "The American Red Cross and the Korean War" in American Red Cross Museum [cited 10 February 2009]: available from http://www.redcross.org/museum/history/korean.asp .

251 "Home Front" in Korean War Educatior [cited 10 February 2009]: available from http://www.koreanwar-educator.org/topics/homefront/index.htm.
} 
participation recreation programs."252 Much as in previous wars, Soldiers relied upon mail and care packages to boost morale. Soldiers received mail from their loved ones often containing familiar or humorous items from home. ${ }^{253}$ Rather than in World War II where victory was its main goal, much of the volunteerism on the home front as the Vietnam War dragged on focused on bringing the war to an immediate end.

The Wars in Afghanistan and Iraq, part of the ambiguously titled "War on Terror," witnessed a resurgence in volunteerism. Thousands of small volunteer groups emerged dedicated to supporting the troops. ${ }^{254}$ Unlike World War II, the United States government did not actively promote and organize volunteer activities and in general citizens were not asked to sacrifice for the war effort, to "give "til it hurts." Mass volunteer efforts in twenty-first century America have largely been relegated to responses to civil crises rather than concentrated war efforts.

The public response to the terrorist attacks on September 11, 2001 has been referred to as a "groundswell of patriotism not seen since World War II."255 Across the nation groups such as the Boy Scouts of America, the American Legion, and even private citizens hung American flags as signs of patriotism and solidarity. In a show of patriotism a Scottsdale, Arizona group of school children built a 1,500 pound flag out of mosaic

252 "The American Red Cross in the Vietnam War" in American Red Cross Museum [cited 10 February 2009] available from http://www.redcross.org/museum/history/60-79_c.asp.

${ }^{253}$ Cyn LoPinto, "Letters from Home-The True Ammunition" in Home Front Magazine [cited 10 February 2009]: available from http://www.homefrontmagazine.com.

254 The Department of Defense keeps a detailed, state by state list of volunteer organizations currently actively supporting soldiers stationed over seas, see: "America Reaches Out" in America Supports You [cited 10 February 2009]: available from http://www.americasupportsyou.mil/americasupportsyou/states.aspx.

For an enlightening article on the resurgence of Volunteerism on the home front see: Daniel Henninger, "The Home Front Comes to Life: America Supports the Troops-Privately, and Online" in Wall Street Journal Online (26 November 2004) [cited 10 February 2009]: available from http://www.homesforourtroops.org/Site/DocServer/Wall_Street_Journal_-_The_Home_Front_Comes_04.pdf?docID=723.

${ }^{255}$ Robert Sullivan, ed., The American Spirit: Meeting the Challenge of September 11 (New York: Life Books, 2002), 13. 
tiles. ${ }^{256}$ Volunteerism and patriotism, just as in World War II, proved to be symbiotic partners. Blood donations across the country increased tremendously in the wake of the attacks. Between September 11 and October 31, 2001, 23,600 Northern Californians donated blood to the Red Cross. Of that number 8,339 were first time blood donors. Together this group donated approximately 5,000 more pints of blood in that month and a half than in previous time periods of the same length. ${ }^{257}$ Other Red Cross locations around the country reported a similar surge of blood donations. Volunteerism in the form of monetary donations also played a large role in the American response to the attacks. Charities raised $\$ 1.4$ billion to aid the families of the victims of the attacks. ${ }^{258}$ The outpouring of volunteerism in the aftermath of the terrorist attacks of September 11, 2001, though fleeting, demonstrated that volunteerism still plays a major role in American responses to crises. ${ }^{259}$

The surge of volunteerism in the aftermath of Hurricane Katrina in 2005 is yet another example of mass volunteerism in the twenty-first century. After the storm, 500,000 Americans journeyed to the Gulf Coast in order to aid in the rebuilding process. 220,000 of this group served with the Red Cross. Many organizations volunteered in some way to alleviate the humanitarian crisis following the disaster. The Catholic

${ }^{256}$ Sullivan, ed. The American Spirit, 164.

${ }^{257}$ Sara O’Brien, "Blood Donations Hit Record Highs Following 9/11: Red Cross Asks Bay Area Residents to Donate Blood Once Again in Honor of 9/11" (Oakland, Ca: Red Cross Headquarters Northern California Region, 2004 [cited 26 January, 2009]) available from http://chapters.redcross.org/ca/norcal/pressroom/archive_2004/09-11-04donations.pdf .

${ }^{258}$ Ray Suarez, "Red Cross Woes" in Online News Hour: A News Hour With Jim Lehrer Transcript, (19 December 2001, [cited 26 January 2009]) available from http://www.pbs.org/newshour/bb/business/july-dec01/redcross_12-19.html .

${ }^{259}$ There are those in academia that have argued that September $11^{\text {th }}$ created a new type of volunteerism in the United States. This will not be discussed here. See:

Seana Lowe and Alice Fothergill, "A Need to Help: Emergent Volunteer Behavior after 9/11" Paper presented at the annual meeting of the American Sociological Association, (Atlanta, GA, 16 August 2003 [cited 26 January 2009]) available from http://www.allacademic.com/meta/p_mla_apa_research_citation/1/0/7/0/8/pages107082-1.php . 
Charities food bank distributed forty million pounds of food. Salvation Army volunteers served over six million hot meals to victims. Volunteers from a group called Traveler's Aid aided 18,725 displaced families. In addition over ten thousand college students traveled to the gulf region during spring break in order to help with reconstruction efforts. The Red Cross, United Way, Boy Scouts of America, YMCA, Campfire Girls USA, Habitat for Humanity, and Junior League International were among the hundreds of volunteer organizations that devoted time and money in the response to Hurricane Katrina. ${ }^{260}$ The American response to Hurricane Katrina is yet another example of mass volunteerism as a response to crises in the United States of America in the twenty-first century.

As the twenty-first century continues, many Californians are still active in local volunteer groups but most Americans are not on a constant look out for voluntary efforts in which to actively participate. When a crisis demands it, Americans are more than ready to aid their fellow man through volunteerism. 9/11 and Hurricane Katrina motivated the average American into action for the greater good and to support his country, much like World War II. Perhaps Roger Lotchin described these types of situations best: these times were "heroic interludes" in which "men, women, and children stepped outside of their normal roles [and] into a heroic perspective."261

260 "More than 500,000 Americans Served in Hurricane Katrina's Aftermath," (18 August 2006 [cited 26 January 2009]) available from http://www.prnewswire.com/cgibin/stories.pl?ACCT+104\&STORY+/www/story/08-18-2006/0004418574\&EDATE= .

${ }^{261}$ Lotchin, The Bad City in the Good War, 242. 


\section{BIBLIOGRAPHY}

America Organizes to Win the War: A Handbook on the American War Effort. New York: Harcourt Brace and Company, 1942.

“America Reaches Out.” In America Supports You. [cited 10 February 2009] . Available from http://www.americasupportsyou.mil/americasupportsyou/states.aspx.

"The American Red Cross in the Korean War." In The American Red Cross. [cited 10 February 2009] . Available from http://www.redcross.org/museum/history/korean.asp.

“The American Red Cross in the Spanish-American War." In The American Red Cross. [cited 12 May 2008] . Available from http://www.redcross.org/museum/history/spanishAmWar.asp .

"The American Red Cross in the Vietnam War." In The American Red Cross. [cited 10 February 2009] . Available from http://www.redcross.org/museum/history/6079_c.asp.

Appleby, Joyce, Alan Brinkley, Albert Broussard, James McPherson, and Donald Ritchie. The American Vision: Modern Times. New York: McGraw Hill Glencoe, 2006.

Bailey, Ronald H. The Home Front: U.S.A. World War II, vol. 8. Alexandria, VA: TimeLife Books, 1977.

Blum, John Morton, V Was for Victory: Politics and American Culture during World War II. New York: Harcourt Brace Jovanovich, 1976.

Block, Ralph. Letter to James D. Stewart. 8 August 1942. Box 45. RG 171. National Archives Laguna Niguel.

Bodnar, John. Remaking America: Public Memory, Commemoration, and Patriotism in the Twentieth Century. Princeton, NJ: Princeton University Press, 1992.

Breuer, William B. The Air Raid Warden Was a Spy: And Other Tales from Home-Front America in World War II. Hoboken, NJ: John Wiley \& Sons, Inc., 2003. . Unexplained Mysteries of World War II. Hoboken, NJ: John Wiley \& Sons, Inc., 1997.

Brokaw, Tom. The Greatest Generation. New York: Random House, 1998. 
“Business Women Buy Defense Bonds.” Santa Maria Daily Times, 7 January 1942, pg. 3.

Butler, Jon. Becoming America: The Revolution Before 1776. Cambridge, MA: Harvard University Press, 2000.

"California Not in Grave Danger, Declares Downey." Santa Maria Daily Times, 8 January 1942, pg. 1.

“Call Issued Here for 15,000 Volunteer Auxiliary Police.” Los Angeles Times, 8 December 1941, pg. 3.

“Campaign Opens for Books for Servicemen.” Santa Maria Daily Times, 19 January 1942,pg. 1.

“Cannon From Other Wars Donated in Redondo Drive." Los Angeles Times, 1 August 1942,pg. 8 .

Carroll, Andrew, ed. War Letters: Extraordinary Correspondence from American Wars. New York: Washington Square Press, 2001.

Carver, Fred L. Letter to All State and Local Defense Councils. "O.C.D. Radio Broadcasts-Columbia Broadcasting System.” Box 55. RG 171. National Archives Laguna Niguel.

"Special Bulletin No. 65:

Civilian Defense Anniversary and Special V-Home Drive!.” Box 55. RG 171. National Archives Laguna Niguel.

Carver, Fred L. Letter to Percy A. Johnson. 10 August 1942. Box 45. RG 171. National Archives Laguna Niguel.

Chan, Sucheng and Spencer Olin, eds. Major Problems in California History. Boston: Houghton Mifflin Company, 1997.

Civilian Protection School 1942-1943. “Command Staff Course.” Box 51. RG 171 National Archives Laguna Niguel.

National Archives Laguna Niguel.

National Archives Laguna Niguel.

171. National Archives Laguna Niguel. 
"Clothes Sent to War Victims." Los Angeles Times, 5 January 1941, sec. B.

“Club Praised on Patriotism.” Santa Maria Daily Times, 10 January 1942, pg. 1.

“Collection of Rubber, Iron Planned." Santa Maria Daily Times, 14 January 1942, pg. 2.

Comic Book Superheroes Unmasked. Produced and Directed by The History Channel. 59 min. Original Air Date: June 23, 2003. Viewed May 4, 2008.

“Coordination of Mercy Work.” Santa Maria Daily Times, 6 January 1942, pg. 3.

"Donors of Blood Organize for War Aid." Santa Maria Daily Times, 22 January 1942, pg. 1.

Eckstein, Susan. "Community as Gift-Giving: Collectivistic Roots of Volunteerism." American Sociological Review 66, no. 6 (2001); 829-851.

Erenberg, Lewis A., and Susan E. Hirsch, ed. The War in American Culture: Society and Consciousness During World War II. Chicago: The University of Chicago Press, 1996.

Forstal, Richard L, ed. "Population of Counties by Decennial Census: 1900 to 1990." In U.S. Census Bureau. [cited 10 October 2008] . Available from http://www.census.gov/population/cencounts/cal190090.txt .

Fountain, Nigel, ed. WWII, The People's Story. Pleasantville, NY: Reader's Digest, 2003.

Fox, Christy. "Society Starts Year in Philanthropic Key." Los Angeles Times, 5 January 1941, sec. D.

Gallup, George. "Survey Shows Campaign for Scrap Metal Success." Los Angeles Times, 12 November 1942, pg. 16.

"Garbage Collector Complains Metal Drives Hurt Business." Los Angeles Times, 30 December 1942, sec. A.

Garvey, John and the California Center for Military History. San Francisco in World War II. Images of America. San Francisco: Arcadia Publishing, 2007.

“Gift Shop Innovation.” Los Angeles Times, 7 December 1941, sec. E.

Goodwin, Doris Kearns. Team of Rivals: The Political Genius of Abraham Lincoln. New York: Simon \& Schuster Paperbacks, 2005. 
“Group Formed to Serve U.S.O.” Santa Maria Daily Times, 14 April 1942, pg. 1.

Gruhzit-Hoyt, Olga. They Also Served: American Women in World War II, New York: Birch Lane Press, 1995.

Harris, Mark Jonathan, Franklin D. Mitchell, and Steven Schechter. The Home Front: America During World War II. New York: G.P. Putnam's Sons, 1984.

Harritt, C. Letter to James D. Stewart.1942. Box 45. RG 171. National Archives.

Harth, Stan, Liz Krieger, and Dan Krieger, eds. War Comes to the Middle Kingdom: Vol. 1 - 1939-1942. San Luis Obispo, CA: EZ Nature Books, 1991.

Henninger, Daniel. "The Home Front Comes to Life: America Supports the TroopsPrivately, and Online." In Wall Street Journal Online. 29 November 2004. [cited 10 February 2009] . Available from http://www.homesforourtroops.org/Site/DocServer/Wall_Street_Journal__The_Home_Front_Comes___04.pdf?.docID=723.

“High School to Plant Garden.” Santa Maria Daily Times, 12 February 1942, pg. 1.

"Historic California Posts: Camp San Luis Obispo." In The California State Military Museum [cited 21 November 2008] . Available from http://www.militarymuseum.org/CSLO\%20History.html .

Hoehling, A.A. Home Front, U.S.A. New York: Thomas Y. Crowell Company, 1966.

"Home Front." In Korean War Educator. [cited 10 February 2009] . Available from http://www.koreanwar-educator.org/topics/homefront/index.htm.

Horne, Lena and Richard Schickel, Lena. New York: Signet Books, 1965.

Howard, John F. Major, Q.M.C. Assistant G-4. "Memorandum to: O.C.D.” 21 October 1942. Box 45. RG 171. National Archives.

“Isoroku Yamamoto Quotes.” In FamousQuotes.com [cited 27 January 2009] . Available from http://www.famousquotes.com/search.php?search=1\&FirstName=Isoroku\&LastN ame $=$ Yamamoto\&foeld=FullName.

“Jap Dad Beats Patriotic Son.” Santa Maria Daily Times, 17 February 1942, pg. 1.

Jardine, John E. Jr. Maj., C.A.C. Acting Director. Letter to Office Personell. "Civilian Defense Radio Show.” 1943. Box 55. RG 171. National Archives. 
Jeffries, John W. Wartime America: The World War II Home Front. Chicago: The American Ways Series, 1996.

“Jewish Council Meeting.” Santa Maria Daily Times, 5 January 1942, pg. 3.

Johnson, Marilynn S. The Second Gold Rush: Oakland and the East Bay in World War II. Berkeley: University of California Press, 1993.

Koith, Willard W. Letter to Office of Civilian Defense Ninth Civilian Defense Region. 10 November 1942. Box 45. RG 171. National Archives.

Koppes, Clayton R. and Gregory D. Black. Hollywood Goes to War: How Politics, Profits \& Propaganda Shaped World War II Movies. New York: The Free Press, 1987.

Litoff, Judy Barrett and David C. Smith, ed. Since You Went Away: World War II Letters from American Women on the Home Front. New York: Oxford University Press, 1991.

“Little Helper in Scrap Drive Dies After Fall." Los Angeles Times, 29 September 1942, pg. 8.

LoPinto, Cyn. "Letters from Home- the True Ammunition." In Home Front Magazine. [cited 10 February 2009] . Available from http://www.homefrontmagazine.com/.

Lotchin, Roger W. "World War II and Urban California: City Planning and the Transformation Hypothesis." The Pacific Historical Review 62, no. 2 (1993): 143171.

. "California Cities and the Hurricane of Change: World War II in the San Francisco, Los Angeles and San Diego Metropolitan Areas." The Pacific Historical Review 63, no. 3 (1994): 393-420. , ed. The Way We Really Were: The Golden State in the Second Great War. Urbana: University of Illinois Press, 2000.

. The Bad City in the Good War: San Francisco, Los Angeles, Oakland, and San Diego. Bloomington: Indiana University Press, 2003.

Lowe, Seana and Alice Fothergill. "A Need to Help: Emergent Volunteer Behavior after 9/11." Presented at the annual meeting of the American Sociological Association. Atlanta, GA. 16 August 2003- [cited 26 January 2009] . Available from http://www.allacademic.com/meta/p_mla_apa_research_citation/1/0/7/0/8/pages 1 07082-1.php . 
MacMillen, Frank. “Scrap Drive May Solve Nation's Steel Problem.” Los Angeles Times, 18 January 1942, sec. A.

Minear, Richard H. Dr. Seuss Goes to War: The World War II Editorial Cartoons of Theodor Seuss Geisel. New York: The New Press, 1999.

"More than 500,000 Americans Served in Hurricane Katrina's Aftermath." 18 August 2006- [cited 26 January 2009] . Available from http://www.prnewswire.com/cgibin/stories.pl?ACCT=104\&STORY=/www/story/08-182006?0004418574\&EDATE $=$.

Native Sons of the Golden West [cited 9 February 2009] . Available from http://www.nsgw.org/index.htm.

New York State War Council. Office of War Training Programs. "Block Leader Instructor's Manual: A Suggested Course for Training Block Leaders in the State of New York," (1942). Box 55. RG 171. National Archives Laguna Niguel.

"Nonagenarian Gives Iron Bed to Uncle Sam for Scrap." Los Angeles Times, 17 August 1942, sec. A.

O'Brien, Kenneth Paul and Lynn Hudson Parsons, ed. The Home-Front War: World War II and American Society. Westport, CN: Greenwood Press, 1995.

O’Brien, Sara. "Blood Donations Hit Record Highs Following 9/11: Red Cross Asks Bay Area Residents to Donate Blood Once Again in Honor of 9/11." Oakland, CA. Red Cross Headquarters Northern California Region. 2004- [cited 26 January 2009 ] . Available from http://chapters.redcross.org/ca/norcal/pressroom/archive_2004/09-1104donations.pdf .

“Oceanside Collects Eighty Tons of Scrap.” Los Angeles Times, 12 November 1942, pg. 16.

“Oceanside History." In City of Oceanside [cited 17 October 2008] . Available from http://www.ci.oceanside.ca.us/datarelation.aspx?content $=113$.

Office of Civilian Defense. "Civilian Intelligence Plan Number 1.” Box 45. RG 171. National Archives Laguna Niguel.

Office of Civilian Defense. Ninth Civilian Defense Region. "Special Bulletin No. 62." Box 55. RG 171, National Archives Laguna Niguel.

55. RG 171, National Archives Laguna Niguel. . "September 25, 1942." Box 
Office of Civilian Defense. Ninth Civilian Defense Region. "Summary of Civilian War Services Staff Conference No. 8 April 12, 13, 14, 1943.” Box 55. RG171, National Archives Laguna Niguel.

Office of War Information. “'Yankee Doodle' Program Number 1.” 31 October 1942.

Box 55. RG 171. National Archives Laguna Niguel.

Ogburn, William Fielding, ed. American Society in Wartime. Chicago: The University of Chicago Press, 1943.

“Ontario Gives Up Cannon in Park.” Los Angeles Times, 9 October 1942, pg. 14.

Parker, Pauline E. ed. Women of the Homefront: World War II Recollections of 55 Americans. Jefferson, NC: McFarland and Company Inc., 2002.

Perrett, Geoffrey. Days of Sadness, Years of Triumph: The American People 1939-1945. New York: Coward, McCann and Geoghegan Inc., 1973.

“Posters Put up for Red Cross.” Los Angeles Times, 15 January 1942, sec. A.

“Ray Hoey Heads Red Cross Work for Coming Year." Santa Maria Daily Times, 6 March 1942, pg. 1.

“Red Cross Here on 24 Hour Basis as Volunteers Sought." Los Angeles Times, 9 December 1941, pg. 13.

“Red Cross Needs for Donations Listed." Santa Maria Daily Times, 7 January 1942, pg. 3.

“Red Cross Will Launch Drive.” Los Angeles Times, 16 December 1941, sec. A.

Rich, Paul. "American Voluntarism, Social Capital and Political Culture." Annals of the American Academy of Political and Social Science 565, (1999): 15-34.

Royse, Frank. Office of Civilian Defense Headquarters Southern California Section. 3 February 1943. Box 45. RG 171. National Archives.

“Safety Zone Buttons to Go in Scrap Drive." Los Angeles Times, 23 July 1942, pg. 1.

“Sale of Defense Bonds Rises Rapidly.” Santa Maria Daily Times, 6 January 1942, pg. 2.

Sánchez, George J. Becoming Mexican American: Ethnicity, Culture and Identity in Chicano Los Angeles, 1900-1945 New York: Oxford University Press, 1993. 
"Santa Barbara Boasts First Complete Evacuation Plan For Coast." Santa Barbara NewsPress, 1 August 1942, sec. A.

“Scrap Rubber Receipts Totaled.” Los Angeles Times, 7 July 1942, pg. 1.

“Sew for Red Cross.” Santa Maria Daily Times, 5 January 1942, pg. 3.

Shanken, Andrew M. "Planning Memory: Living Memorial in the United States during World War II." The Art Bulletin 84, no. 1 (2002): 130-147.

“Shrapnel Rained on LA when Planes Reported." Santa Maria Daily Times, 25 February 1942,pg. 1.

Sittser, Gerald L. A Cautious Patriotism: The American Churches and the Second World War. Chapel Hill: The University of North Carolina Press, 1997.

Skocpol, Theda, Marshal Ganz, and Ziad Munson. "A Nation of Organizers: The Institutional Origins of Civic Voluntarism in the United States." American Political Science Review 94, no. 3 (2000): 527-546.

Starr, Kevin. Embattled Dreams: California in War and Peace, 1940-1950. Oxford: Oxford University Press, 2002.

. California: A History. New York: The Modern Library, 2005.

Suarez, Ray. "Red Cross Woes.” In Online News Hour" A News Hour With Jim Lehrer Transcript. 19 December 2001- [cited 26 January 2009] . Available from http://www.pbs.org/newshour/bb/business/july-dec01/redcross_12-19.html .

Sullivan, Robert, ed. The American Spirit: Meeting the Challenge of September 11. New York: Life Books, 2002.

Takaki, Ronald. Double Victory: A Multicultural History of America in World War II. Boston: Little, Brown and Company, 2000.

Terkel, Studs. “The Good War:” An Oral History of World War Two. New York: The New Press, 1984.

“They Also Served: Actors With WWII Military Records.” In Combat! [cited 24 November 2008] . Available from http://www.jodavidsmyer.com/combat/military/actors_in_wwii.html .

Verge, Arthur C. "The Impact of the Second World War on Los Angeles." The Pacific Historical Review 63, no. 3 (1994): 289-314. 
"Vessel with Relief Supplies for Greece to Sail Next Week." Los Angeles Times, 9\ January 1941, pg. 4.

War Disaster Relief Plan Reports 1942-1943. "Compton.” Box 52. RG 171. National Archives Laguna Niguel.

National Archives Laguna Niguel.

. "Imperial County.” Box 53. RG 171.

. "Imperial City." Box 53. RG 171. National

Archives Laguna Niguel.

. "Lompoc." Box 53. RG 171. National Archives

Laguna Niguel.

. "Los Angeles City." Box 53. RG 171. National

Archives Laguna Niguel.

. “San Luis Obispo.” Box 54. RG 171. National

Archives Laguna Niguel.

. "Santa Barbara." Box 54. RG 171. National

Archives Laguna Niguel.

National Archives Laguna Niguel.

."Santa Barbara County." Box 54. RG 171.

. "Santa Maria." Box 54. RG 171. National

Archives Laguna Niguel.

“War Refugee Children See Wild West for Themselves.” Los Angeles Times, 6 January 1941 , sec. A.

Ward, Geoffrey C. and Ken Burns. The War: An Intimate History 1941-1945. New York: Alfred A. Knopf, 2007.

“Warning Posts Need Help.” Santa Maria Daily Times, 29 January 1942, pg. 1.

Weatherford, Doris. American Women and World War II, New York: Facts on File, 1990.

Wilson, Bess M. "Girl Scouts Mobilize for Community Service." Los Angeles Times, 12 January 1941, sec. D. 
Wong, K. Scott. Americans First: Chinese Americans and the Second World War. Cambridge, MA: Harvard University Press, 2005.

"World War I Accomplishments of the American Red Cross." In The American Red Cross [cited 12 May 2008] . Available from http://www.redcross.org/museum/history/ww1a.asp .

"World War II on the Home Front: Civic Responsibility." In Smithsonian in Your Classroom. Fall 2007- [Cited 31 May 2008] . Available from http://www.smithsonianeducation.org/educators/lesson_plans/civic_responsibility /smithsonian_siyc_fall07.pdf .

“'Y' Funds Only One-Fourth Raised.” Santa Maria Daily Times, 10 April 1942, pg. 1.

Yellin, Emily. Our Mother's War: American Women at Home and at the Front During World War II. New York: Free Press, 2004. 